\title{
Informal Electronic Waste Recycling in Pakistan
}

\author{
SHAKILA UMAIR
}

Licentiate Thesis, in

Planning and Decision Analysis, with specialisation in

Environmental Strategic Analysis

KTH Royal Institute of Technology

School of Architecture and the Built Environment

Department of Sustainable Development, Environmental

Science and Engineering

Division of Environmental Strategies Research and

KTH Centre for Sustainable Communications 

Cover photo: Hands of a ewaste dismantler Rawalpindi Pakistan Photo by: Shakila Umair

TRITA-INFRA-FMS-LIC 2015:01

ISSN 978-91-7595-574-2

Printed by US-AB in Stockholm, Sweden 2015 



\begin{abstract}
The aim of this thesis was to study governance aspects of informal electronic waste recycling and to provide better knowledge of the business in terms of structure, stakeholders, governance aspects and social impacts.
\end{abstract}

The thesis consists of a cover essay and two papers appended at the end of the thesis. The cover essay summarizes the papers and puts them in context. The objective of Paper I is to study the business of informal electronic waste recycling in Pakistan and highlight its governance issues. Paper II assesses the social impacts of this business using UNEP-SETAC Guidelines for Social Life Cycle Assessment.

The thesis examines these specific questions: Q1) What is the current situation of informal e-waste recycling in Pakistan? Q2) Who are the important stakeholders and what are their roles in this business? Q3) What are the governance issues enabling this informal business? Q4) What are the social impacts for individuals and society arising from this business?

Paper I presents the international and local e-waste flows, business structure, the stakeholders involved and the existing governance issues of the business. It shows weak enforcement of legislation, the complexities emerging with numerous stakeholders, the profitability of informal recycling, little concem for the health damaging exposure for workers from the poorest and most vulnerable people in society, and lack of awareness of the hazards involved. The paper also highlights how this 
business lacks characteristics of good governance, which makes it a challenge to control this business.

Paper II assesses the social impacts of informal e-waste recycling in Pakistan using UNEP/ SETAC guidelines for conducting a Social Lifecycle Assessment (SLCA). It showed that this business has positive impacts relating to societal issues and individual/family economics, and in the economic development of Pakistan but otherwise most impacts are negative. The findings of Paper II fill an important data gap and can be integrated with data on other stages of ICT product lifecycle to produce a full SLCA of such products. 


\section{Sammanfattning}

Syftet med denna avhandling var att studera förvaltning och styrning av informell återvinning av elektroniskt avfall och att ge bättre kunskap om verksamheten i fråga om struktur, intressenter, styrningsaspekter och sociala konsekvenser.

Avhandlingen består av en kappa och två vetenskapliga artiklar. Kappan sammanfattar artiklarna och sätter dem i sitt sammanhang. Syftet med Artikel I är att studera informell återvinning av elektroniskt avfall i Pakistan och belysa dess styrningsfrågor. I Artikel II bedöms de sociala konsekvenserna av denna verksamhet med hjälp av UNEP-SETAC riktlinjer för social livscykelanalys.

Avhandlingen undersöker dessa frågor: Q1) Vad är den nuvarande situationen för informell återvinning av elektroniskt avfall i Pakistan? Q2) Vilka är de viktigaste intressenterna och vilka är deras roller i den här branschen? Q3) Vilka aspekter av styrning och förvaltning möjliggör denna informella verksamhet? Q4) Vilka är de sociala konsekvenserna för enskilda och samhället av denna verksamhet?

Artikel I presenterar internationella och lokala flöden av elektronikavfall, företagsstruktur, de inblandade aktörerna och befintliga aspekter av styrning av verksamheten. Det visar på svag tillämpning av lagstiftning, komplexitet till följd av det stora antalet intressenter, lönsamheten i informell återvinning, brist på omsorg om fattiga och utsatta arbetstagares hälsa och brist på medvetenhet om verksamhetens risker. Studien belyser också hur denna verksamhet saknar egenskaper av god 
styrning och förvaltning, vilket gör det till en utmaning att styra denna verksamhet.

Papper II bedömer de sociala konsekvenserna av informell återvinning av elektronikavfall i Pakistan med hjälp av UNEP/SETAC riktlinjer för social livscykelanalys (SLCA). Studien visar att denna verksamhet har positiva effekter på individers och familjers ekonomi, och på den ekonomiska utvecklingen i Pakistan men i övrigt var de flesta effekterna negativa. Resultaten av studien fyller en viktig kunskapslucka och kan integreras med uppgifter om andra stadier av elektroniska produkters livscykel för att göra en full SLCA av sådana produkter. 


\section{Acknowledgements}

First of all thanks to Almighty Allah for providing me with the abilities to be able to accomplish everything during this project. I would like to dedicate this work to my uncle Shahwali Khan (late), my mom and my dad, without their efforts I would have not been where I am today.

Also this project would have been impossible without the funding and support from Swedish International Development Cooperation Agency (SIDA), Centre for Sustainable Communication (CESC) and Division of Environmental Strategies Research (FMS). I would like to express my gratitude to Dr. Stefan Anderberg (Linköping University), who provided me the opportunity to work on this project. My heartfelt gratitude to Associate Professor Anna Björklund who has been a mentor to me and her constant guidance and kind support have always pulled me out of any difficulty I faced throughout my work. I would like to thank Professor J osé Potting, my main supervisor, for her supervision. She molded my thought process and improved my approach and work manyfold during the course of the research. Great thanks to Professor Mattias Höjer for everything; all the encouragement, support and his positivity brought me one step closer to my goals. Thank you to Elisabeth Ekener Petersen for co-authoring the paper included herein with me and guiding me about SLCA. I would also like to thank Anna Björklund, Stefan Anderberg and J osé Potting for co-authoring papers presented in this thesis.

A very special thank you to my brilliant bosses Åsa Moberg, Annica Carlson, Åsa Svenfelt and Anna Kramers who were always there to help me out and showed their kind understanding and support no matter what the circumstances. This journey has had its ups and downs but working in two departments with the best of the colleagues one can't thank enough. I 
would like to thank Greger Henriksson, Åsa Nyblom, Miriam Börjesson Rivera, Carlos Cano Viktorsson, Jacob von Oelreich, Yevgeniya Arushanyan, Carolina Liljenström, Eléonore Elfström Fauré, Mohammad Ahmadi Achachlouei, Nils Brown, Sofia Poulikidou, Sofia Miliutenko, and Josefin Wangel for their moral support, fikas and lunches and for providing me with the right kind of advice when I needed it the most. A huge thanks to Bernhard Huber for always appreciating my work and if it wasn't for him, no one would have known about my work outside the university, thanks for all the help with the media coverage. An equally huge thanks to Daniel Vare, J oanna Leksell and Caisa Naeselius for all their immediate help with everything.

I am grateful to my husband Umair for his unlimited support and encouragement. My kids Aimen and Musab were constant source of joy and relieved my stress when going got tough. I am grateful that they let me squeeze my work into their childhood. I am extremely thankful to my friends for all their help, support, and encouragement. I am ever grateful to my parents-in law for their motivation, prayers and their support especially during my field trips. Thank you to my siblings for their love and support.

The last but not the least I am thankful to all the workers and stakeholders I interviewed for my studies, and all the drivers and guides who helped me in my field trip. Despite the secretive nature of their work all the information they provided turned out to be the cornerstone of my thesis. Thank you to my husband Umair and cousin Abubakr Rasheed who accompanied me to Mafia controlled areas.

At the end I would like to thank my family and friends who have supported me all along and showed understanding throughout my work. 


\section{Contents}

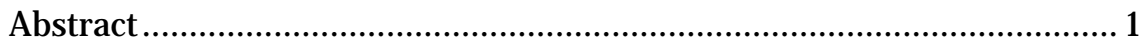

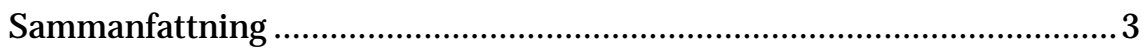

Acknowledgements................................................................................ 5

List of papers included ............................................................................

1 Introduction and rationale behind the study .....................................11

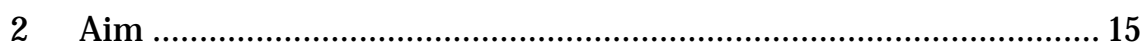

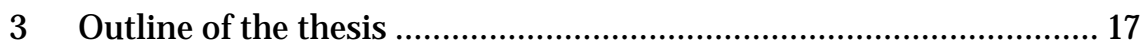

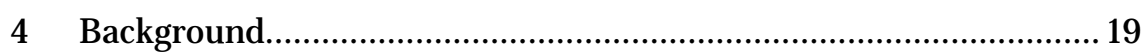

4.1 Increasing Information Communication Technology (ICT) .... 19

4.2 Management of e-waste ........................................................20

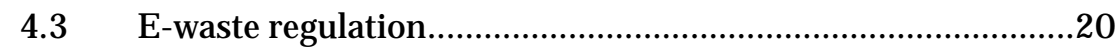

4.4 Formal recycling of e-waste ...................................................22

4.5 Informal recycling in developing countries ...............................24

4.6 Pakistan and its e-waste recycling activities.............................26

4.7 Importance of e-waste for the life cycle perspective of ICT

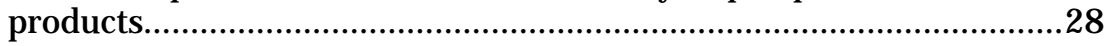

5 Scientific framework and methodological approach ........................... 31

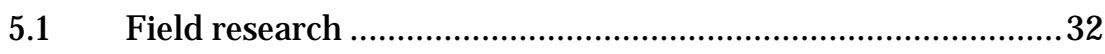

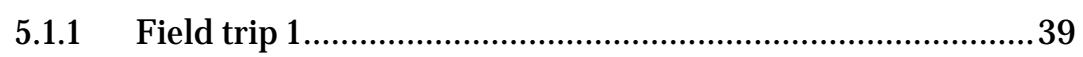

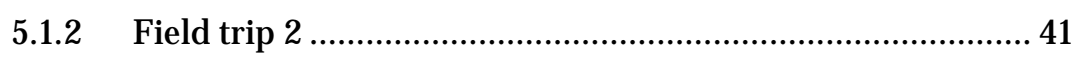

5.2 Data collection through questionnaire and interviews..............43

5.3 Governance analysis...........................................................46

$5.4 \quad$ Social Life Cycle Assessment (SLCA) ..........................................4 47

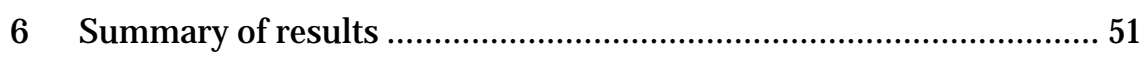

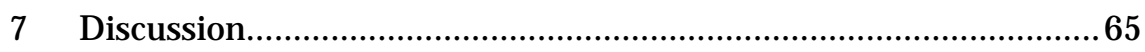

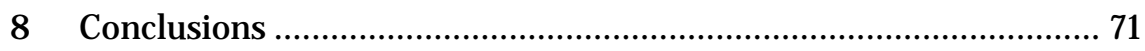

9 How to improve e-waste recycling in Pakistan................................... 73

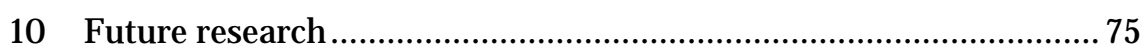

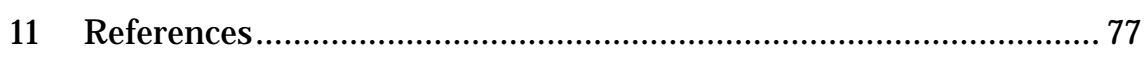




\section{List of papers included}

\section{Paper I}

Umair, S., Anderberg, S., Potting, J . Informal electronic waste recycling in

Pakistan. Submitted to Journal of Solid Waste Technology and Management.

\section{Paper II}

Umair, S., Björklund, A., Ekener-Petersen, E. 2015. Social impact assessment of informal recycling of electronic ICT waste in Pakistan using UNEP SETAC guidelines. Resources, Conservation \& Recycling 95, 4657.

Paper I

Stefan Anderberg and I were responsible for writing the main structure of the article. I was responsible for data collection for the study. Stefan Anderberg supervised and contributed useful feedback and input on the governance aspect of the paper. José Potting supervised my work and contributed written contributions and useful input and feedback. 


\section{Introduction and rationale behind the study}

Electronic waste (e-waste) is one of the largest and fastest growing waste streams world-wide (BAN, 2002; Wei et al., 2012). It has become a problem to manage this growing waste stream, especially in developing countries (Sthiannopkao et al., 2013). This thesis examined the business of informal e-waste recycling in a developing country facing this problem, using the example of Pakistan. The analysis concentrated on governance issues and the social impacts of the business.

There is no exact definition of e-waste. Some definitions only include electronics that are no longer working, but others also include fully functioning items that have been disposed of by the original user for other reasons. According to the EU Directive on Waste Electrical and Electronic Equipment (WEEE), e-waste is defined as obsolete equipment that is dependent on electric currents or electromagnetic fields to work properly. It includes large and small electrical household appliances, information and communications technology (ICT) equipment etc. (EU, 2003). The Swedish Environmental Protection Agency (SEPA) includes in its definition of e-waste any equipment that has been disposed of by the original owner because it is no longer able to perform the purpose assigned to it by that owner (SEPA, 2011). Thus it may be damaged or simply not up to date (Tanskanen, 2013). The United Nations Environment Programme (UNEP) considers electronics destined for "reuse, resale, salvage recycling and disposal" as e-waste (UNEP, 2011). This thesis deals with e-waste of ICT products (i.e. excludes other electrical equipment). Thus e-waste in this thesis includes products that have become obsolete; have been disposed of by the original owner; are damaged; or are destined for resale, reuse, recycling and disposal. ICT 
products include end user devices (personal computers (PCs), mobile devices, peripherals), telecommunications networks (fixed line, wireless), and data centres (servers, storage systems, cooling systems) (Arushanyan, 2013).

In the remainder of this thesis, the term 'e-waste' is used for all equipment discarded by the first (and later) users. It thus includes second-hand equipment. The term 'true e-waste' is used exclusively for equipment, working or not, which is intended to be recycled and not to get a second life. The term 'true second-hand equipment' is used exclusively for working or refurbishable equipment intended to get a second life.

Studies show that the majority of this waste enters the informal recycling chains in developing countries for end-of-life treatment. Pakistan is one of these countries. However, informal recycling and its impacts have rarely been studied in Pakistan to date. It is important to study how, despite national/international legislation forbidding the trade; e-waste enters the country. Important questions include: What is the business structure? Who are the stakeholders involved? and Which factors make this business a challenge to control, because it has significant impacts on the people and environment of Pakistan? Lack of data on the environmental, social and economic impacts of informal recycling in developing countries and lack of application of such data in a life cycle perspective hamper assessment of the overall impacts of ICT waste products. Thus this makes it difficult to suggest possible solutions for improving the situation prevailing in the informal sector of e-waste recycling. Therefore there is a need to study the governance aspects of this business, and to assess the impacts caused due to governance 
loopholes by collecting data on the impacts of informal recycling and applying it in Life Cycle Assessments (LCA). 


\section{Aim}

The aims of this thesis work were to use the case of informal e-waste recycling in Pakistan as an example to study the current social impacts and governance aspects of this business; and to provide better knowledge of the business in terms of structure, stakeholders, governance aspects and social impacts.

As a part of this work, the following research questions were studied:

Q1. What is the current situation of informal e-waste recycling in Pakistan? This included determination of:

- $\quad$ Sources of e-waste entering the informal recycling sector

- Flows of e-waste, both international and domestic

- $\quad$ Processes of informal e-waste recycling

- Market mechanisms and how they operate

- $\quad$ Possible social, health and environmental impacts.

Q2. Who are the important stakeholders and what are their roles in this business?

Q3. What are the governance issues enabling this informal business? This included:

- Scrutiny of existing legislation and its enforcement

- Identification of important missing stakeholders and the consequences of their absence

- Identification of driving forces of this business

- Determination of governance weaknesses of this business. 
Q4. What are the social impacts for individuals and society arising from this business? This involved:

- Collection of data for inventory analysis of social impacts

- Assessment of social impacts of the business.

By providing an in-depth understanding of the situation of informal recycling of e-waste in Pakistan, the work was expected to identify governance weaknesses and the social impacts of this business, thus identifying and highlighting the issues of this business in a way that can hopefully help improve the current situation in Pakistan. It was also intended to help provide a less skewed picture of ICTs when considered in the life cycle perspective, by filling the data gaps that exist due to unknown social impacts of informal recycling. 


\section{Outline of the thesis}

The thesis consists of this cover essay and two research papers appended at the end. Paper I focused on governance aspects (Q1-3) of e-waste recycling and Paper II on social impacts (Q4). Chapters 1 and 2 of this cover essay introduced the study and itemised the research questions appended. Chapter 4 sets the background for the work and the case study of Pakistan; Chapter 5 introduces the scientific framework and methodological approach used in these papers and Chapter 6 and 7 discuss the results and major findings of the papers briefly, based on the research questions. Conclusions are drawn in Chapter 8. Chapter 9 discusses some possible solutions and how they can be applied in order to improve this problem. Finally, in light of the results presented in this thesis, future research areas are discussed in Chapter 10. 


\section{Background}

\subsection{Increasing Information Communication Technology (ICT)}

Production of Electrical and Electronic Equipment (EEE) is one of the largest and fastest growing business sectors in Europe (Babu et al., 2007). It has become so in order to cater for the increasing demand for these products. This increase in production and demand for EEE can be attributed to increased use of a specific group of EEE products, i.e. ICT products. For example, it was reported that the number of PCs around the world exceeded 1 billion in 2008 (Tanskanen, 2013). This trend for increasing use of ICT products is not only being followed by the developed countries, but also the developing countries.

The number of PC users in China increased by 1052\% from 1993 to 2000, while in India it increased by 604\% from 1996 to 2002 (Streicher-Porte et al., 2005). Similarly, in the case of mobile phones, $61 \%$ of the world's mobile phones are used in developing countries (GSMA, 2011). Penetration of ICT has been improving the lives of people in both developed and developing countries, but there is also a downside to this technology. Rapid changes in ICT, their versatility and lower price have led to their lifespan being drastically reduced (Osibanjo et al., 2007; Davis et al., 2007; Tanskanen, 2013). This reduced lifespan is leading in turn to one of the fastest growing waste streams in the world that of electronic waste (e-waste). Recent figures show that e-waste constitutes on average $8 \%$ of the global municipal waste stream (Bandyopadhyay, 2010), corresponding to 40 million tons per year in 2008 (Wang et al., 2013). Europe produces 8.3-9.1 million tons of e-waste annually (UNU, 
2007; UNEP, 2011). Globally, this quantity is growing at a rate of $3-5 \%$ per year (Hester et al., 2009).

\subsection{Management of e-waste}

The e-waste produced at the end of the life of ICT products requires proper handling, because it is toxic (Brett, 2009), but also valuable (Wei et al., 2012). If e-waste is properly handled, this ensures recycling and recovery of rare precious metals, as well as controlling toxic leakages into the environment (SEPA, 2011). It also provides safe working conditions for workers and people involved in the business (Khetriwal et al., 2005).

According to Premalatha (2013), only a few countries in the developed world are able to properly recycle or dispose of the e-waste they generate. Thus only a fraction of the e-waste generated is properly recycled through formal recycling. It has been shown that a country such as the US, which is one of the largest producers of e-waste (BAN, 2002), formally recycles only $13.6 \%$ of its e-waste (Takeback Coalition, 2009). The UK recycles only $17 \%$ (Ewaste, 2011). In the EU as a whole, 60\% is recycled through formal recycling. The rest is either stockpiled by owners (Wagner, 2009), landfilled (Ongondo et al., 2011; Khurrum et al., 2011) or shipped to developing countries (Williams et al., 2008; Oteng-Ababio, 2010) for component recycling. E-waste thus poses a serious challenge in terms of its disposal and recycling in both developed and developing countries (Needhidasan et al., 2014).

\subsection{E-waste regulation}

In order to prohibit transport of e-waste from developed to developing countries and to tighten waste legislation in developed countries, the 
Basel Convention came into force in 1992. This Convention inhibits the transboundary movement of hazardous waste, including e-waste, from developed to developing countries. Although 170 countries became signatories to this Convention, there were three key gaps or loopholes in its content (Lepawsky et al., 2010). The first was absence of a clear definition of hazardous substances and what the term included. The second was that the Convention allowed bi-lateral and multi-lateral agreements between Basel signatories and non-signatories regarding transboundary movement of e-waste, as long as they were environmentally sound, but this again lacked a definition of what can be called environmentally sound. The third was that the Convention allowed transboundary movement of hazardous substances if they were destined for reuse or recycling. This enabled legal transboundary movement of hazardous waste labelled as second-hand products destined for reuse and recycling (Lepawsky et al., 2010). Thus shipping of e-waste to developing countries became legal if the e-waste was labelled as second-hand and/ or was destined for reuse and recycling. These loopholes led to the creation of the Basel Ban, which completely prohibits transboundary movement of any hazardous substance, even if it is destined for reuse and recycling. However, the Basel Ban has yet not been enforced and therefore there are still flows of e-waste to Asian and African countries (SEPA, 2011).

With regard to e-waste, the EU has made efforts to tighten its regulations. Its WEEE directive 2002/96/EC was introduced in 2003 to prevent movement and trade in WEEE and to introduce Extended Producer Responsibility (EPR). It initially set a target for collecting, recycling and recovery of $4 \mathrm{~kg}$ e-waste/capita/year (EC, 2003). This target has since been replaced in the latest WEEE directive (2012/19/ EU) and now states that by 2016, the minimum collection rate must be $45 \%$ of the average weight of EEE placed on the market in the three preceding years. This is 
intended to reduce the impact of disposal of electronic products. The Restriction on certain Hazardous Substances (RoHS) (Directive 2002/ 95/ EC) was implemented in 2003. It enforces the use of substitutes or safer alternatives for heavy metals such as lead, mercury, cadmium and hexavalent chromium and flame retardants such as polybrominated biphenyls (PBB) and polybrominated diphenyl ethers (PBDE) (EC, 2003). The WEEE directive requires that e-waste be collected at the end of its life for proper disposal, while the RoHS requires that new EEE products do not use the six toxic materials listed in the directive in their manufacture. This is intended to result in better management of these products at the end of their life.

\subsection{Formal recycling of e-waste}

For proper management of the e-waste stream and to recover precious metals, recycling is one of the best alternatives. E-waste can be recycled both through formal and informal recycling processes. Formal recycling is preferable, as it ensures worker safety and involves use of state-of-the-art technology for processing e-waste. It can recover up to $80 \%$ of the materials contained in e-waste and about $15 \%$ of the energy. Only about $5 \%$ of the materials end up in the waste stream (SEPA, 2011). It has been shown that 95\% extraction of gold, silver, copper, nickel, iron, zinc and aluminium is possible with available technologies (Ladou et al., 2008). Such extraction is mostly carried out in developed countries, where strict regulations ensure control of emissions released into environment as a result of these processes. In short, formal recycling of e-waste follows these major steps: 
- Collection

Proper collection takes place from homes/shops/offices, or consumers deposit old equipment at the closest recycling facility.

- Manual dismantling

Simple removal of different parts or disassembly of components is involved in this process (Babu et al., 2007). Components that are separated out may be divided into reusable and recyclable or valuable. Mercury-containing components require special treatment for recovery of the mercury. Therefore those components are removed and recycled in specialist mercury recycling facilities (SEPA, 2011).

\section{- Shredding and processing}

In this process, the recyclables are shredded/crushed and then sorted according to their physical properties through processes such as screening, magnetic separation (ferrous metals), eddy current separation (for nonmagnetic materials, e.g. copper, aluminium etc.) and density/gravity separation (plastics) (SEPA 2011).

\section{- Metallurgical processing}

Metallurgical processes include recovery of nonferrous metals and precious metals by pyrometallurigical (metal melting) and hydrometallurgical (metal dissolving) means (SEPA, 2011).

\section{- Cathode ray tube recycling}

A cathode ray tube (CRT) contains $0.68-2.72 \mathrm{~kg}$ of lead and therefore requires proper handling in order to avoid losses to air, soil and water. A CRT consists of both glass and non-glass components. After separation of these components, the process mostly involves glass to glass and glass to lead recycling. So far, 
the best disposal technique for CRT is to recycle it into new CRT glass (Babu et al., 2007).

\section{- Plastic recycling}

One of the major components of e-waste is plastics. This waste material has the next highest potential for recycling value, after metals (SEPA, 2011).

\subsection{Informal recycling in developing countries}

The higher cost of formal recycling and stricter regulations in developed countries cause a flow of true e-waste to developing countries with weaker legislation (Lepawsky et al., 2010). This includes countries such as China, India, Pakistan and Nigeria. These countries are among the largest receivers of e-waste (Sthiannopkao et al., 2013). As there has been an unequal distribution of ICT products between developed and developing countries, this causes a digital divide. Developing countries are dependent on imported second-hand ICT equipment for the mitigation of this digital divide (BAN, 2005). This ICT equipment mainly comprises items that have come to the end of their life in developed countries.

The penetration of ICT has been fast in developing countries, but these countries lack the infrastructure to manage the e-waste resulting at the end of life of these ICT products (Oteng-Ababio, 2010). Thus in developing countries this e-waste is recycled by informal recycling processes. These processes are a concern, as they have negative social and environmental impacts (Williams et al., 2008; Manhart et al., 2011; Sthiannopkao et al., 2013). 
The process of informal recycling of e-waste includes:

- Dismantling

This process includes physical dismantling of the equipment. This is usually done with basic tools and bare hands. Another way of dismantling is to remove the components from printed circuit boards by high flame torch or heating. Refilling and sweeping of toner cartridges are also carried out manually.

- Extracting precious metals

Extraction of precious metals takes place using acid baths. Old motherboards, processor chips and components containing precious metals are dipped in acid, where the plastic and other components melt into the acid, leaving behind the precious metals.

\section{- Recovering copper from cable}

Copper can be extracted from cable by burning the cables. This process burns off the plastic and leaves behind the copper (BAN 2002; Chi et al., 2011).

These processes are carried out with basic tools and no protective gear (Sthiannopkao et al., 2013) and therefore have health impacts on the workers involved. Due to the toxic nature of this waste, informal recycling also has various environmental impacts (Li et al., 2008; Williams et al., 2008; Sthiannopkao et al., 2013). These processes are easily carried out in developing countries, as they have weaker legislation (Babu et al., 2007; Bandyopadhyay, 2010).

Despite the fact that informal recycling is a polluting and dangerous business compared with formal recycling, it is still a very attractive business in developing countries. The simplicity and smaller investment 
make it more profitable than formal recycling (Kehtriwal et al., 2007; Chi, 2011). It is also an important source of livelihood for the people involved. Guiyu in China alone has 150,000 workers (Chi et al., 2011), while in Delhi in India about 10,000 workers are involved in informal e-waste recycling (Khetriwal et al., 2005). It is also an important source of raw materials for the industries in those countries (Yu et al., 2010).

\subsection{Pakistan and its e-waste recycling activities}

The Islamic Republic of Pakistan is located in South East Asia and is a developing country. It was formerly part of the Indo Pak Subcontinent and became an independent state on 14 August 1947. It is the sixth most populous country in the world, with an estimated population of more than 185 million, 37\% of whom live in urban areas (Worldmeter, 2015). The territory of Pakistan comprises 796,100 sq. $\mathrm{km}$ as measured in 20102014 (WorldBank 2015a). It is divided into eight administrative units, namely Islamabad Capital Territory, Federally Administrated Tribal Area (FATA), Gilgit/Baltistan, Azad Kashmir and the four provinces Punjab, Sindh, Khyber Pakhtun Khwa (KPK) and Baluchistan. Each administrative unit has a capital city, which is also the largest city in the unit. These capital cities are Rawalpindi/Islamabad (Islamabad Capital Territory), Gilgit (Gilgit/Baltistan), Muzaffarabad (Azad Kashmir), Lahore (Punjab), Karachi (Sindh), Peshawar (KPK \& FATA) and Quetta (Baluchistan). Geographically, Pakistan occupies an important position, as it acts as the gateway to Central Asia. It is important in promoting the transit economy and has become China's link to the Middle East. Pakistan also plays a vital role among Muslim countries, as it is located in the centre of African and Asian Muslim countries (Rehman, 2014). 
Pakistan is governed based on a federal parliamentary system. The President is the head of state, while the Prime Minister is the head of government. The country has a bicameral federal legislature which compromises the Senate (upper house) and the National Assembly (lower house). The judicial system consists of the Supreme Court, provincial high courts, Federal Shariat courts and other lesser courts exercising civil and criminal jurisdiction (Blood, 1994). Pakistani law is based on the legal system of British India and the Common Law of England and Wales. It further builds on the much amended 1973 constitution and Islamic law (Shariah). An elaborate legislative structure exists in Pakistan (Hussain, 2011), yet the system lacks legitimacy due to low levels of efficiency, the prevalence of long delays, the inferior quality of legal training, corruption and the perception that the court system is a tool for delaying justice, manipulated by rich and/or powerful interests in society (Blue et al., 2008).

Gross domestic product per capita in Pakistan in 2013 was estimated to be USD 1275.30, which was lower than in the neighbouring countries of India (WSD 1497.5), China (USD 6807.4) and Iran (USD 4763.3), but higher than in Afghanistan (USD 664.76) (WorldBank, 2015b). Pakistan is ranked $153^{\text {rd }}$ out of 193 countries in the world on the basis of its $\mathrm{GDP} /$ capita. It has an unemployment rate of $5.2 \%$ and an inflation rate of $7.2 \%$ (WorldBank, 2015c). Moreover, 60\% of the population live below the poverty line, earning less than USD 2 per day (Bauer et al., 2008).

Corruption and lack of transparency and accountability prevail at all levels of government, leading to political instability (The Heritage Foundation, 2015). Pakistan also faces terrorism issues (Nizami et al., 2014), an energy crisis (Awan et al., 2014), social and economic problems (The Economist, 2011) and environmental issues (Gabol et al., 2011). 
E-waste is one of the contributors to the environmental and public health issues faced by Pakistan (BAN, 2002). Pakistan is one of the largest receivers of e-waste and second-hand equipment, along with China, India and Nigeria (Sthiannopkao et al., 2013). Some of the source countries dispatching e-waste to Pakistan include Australia, Japan, England, United States, European Union, Kuwait, Saudi Arabia, Singapore and United Arab Emirates (UAE) (BAN, 2002; Greenpeace, 2009; Sthiannopkao et al., 2013) There is various legislation, both national and international, to prohibit flows of e-waste from developed to developing countries, yet e-waste still makes its way to Pakistan. Although the majority of this e-waste enters the country as donations by charities or second-hand equipment, only $2 \%$ of the bulk is reusable or can be repaired and reused. The rest is recycled by informal recyclers (BAN, 2002; Sthiannopkao et al., 2013).

\subsection{Importance of e-waste for the life cycle perspective of ICT products}

It has been shown that proper end-of-life disposal of e-waste provides the potential to achieve a lower life cycle environmental impact (Arushnayan, 2013). Most LCAs of ICT products assume state-of-the-art formal recycling as the end-of-life (EoL) scenario for these products (ibid). However, the majority of e-waste in developing countries ends up in the informal recycling sector (Ongondo et al., 2011). Assuming formal recycling at the EoL is thus in many cases not the most appropriate scenario to study in the life cycle perspective. In LCAs, it is permissible to delete life cycle stages or processes which might not have a significant impact (ISO 14044, 2006). When informal recycling is kept out of the system, however, it may result in a significant impact being 
eliminated/ignored. Studies show that processes such as artisanal mining and e-waste recycling, the latter at the end of supply chains, have several negative social and environmental impacts (Williams, 2008). Consequently, excluding this life cycle stage of ICT products while conducting LCA might give a skewed picture of these products. Therefore there is a need to add these processes when taking a life cycle perspective into consideration. Informal recycling is now mostly kept out of the system due to lack of data. It is therefore important that data are made available to allow these assessments to be carried out. 


\section{Scientific framework and methodological approach}

The amounts of e-waste being shipped to Pakistan are huge, but there has been very little work in reference to Pakistan in this study area. There has been no detailed study of the social or environmental impacts caused by these imports. There is therefore an urgent need to collect on-site empirical data regarding this business, its relevant processes and their impacts, as outlined in

Figure 1, which illustrates the research design of this thesis. Two field trips were made to Pakistan in order to collect data for the analysis conducted in this thesis. For Paper I, data were collected through field trip 1, including observations of the sites, interviews with the stakeholders and a review of relevant documents, e.g. import lists etc. A literature review was conducted to further verify the findings. These findings were applied to conduct a governance analysis that led to provision of basic data answering research questions Q1, Q2, and Q3 and helped in the development of Paper I. The findings were further used in the development of Paper II and to answer research question Q4. Field trip 2 was conducted to collect detailed data on social impacts for Paper II. Observations were made, interviews were conducted and relevant documents were studied to collect these data. The data obtained were again further elaborated upon and verified through a scientific and policy-based literature review. These findings were applied in the Social Life Cycle Assessment (SLCA) framework to develop Paper II. 


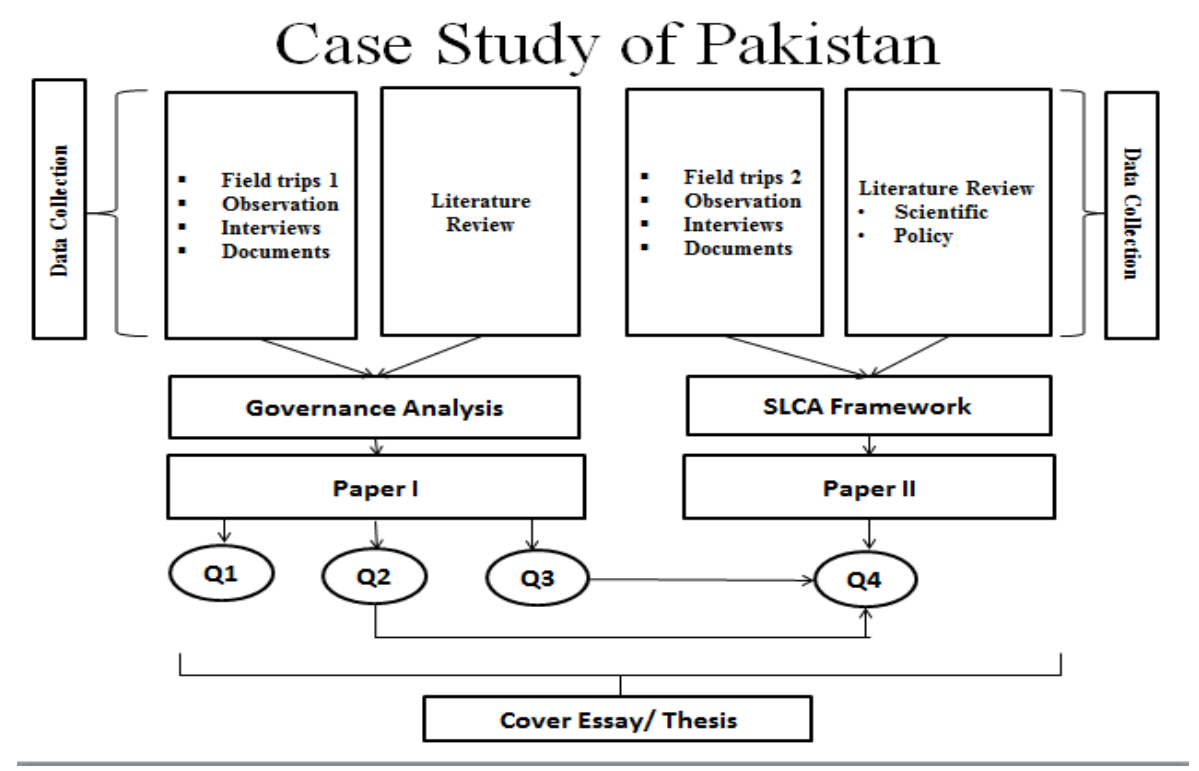

Figure 1 Outline of scientific and methodological approaches used in Papers I and II in this thesis.

\section{$5.1 \quad$ Field research}

In order to collect empirical data, two in-depth field studies were carried out at the main e-waste recycling sites in Pakistan. These comprised exploratory studies, with limited information about this business available beforehand. The experiences, observations and interviews conducted in the field helped further structure the approach used in the studies. For instance, it was planned beforehand that relevant stakeholders would be identified and interviewed in order to study the business structure. The initial idea was to use a top-down approach, where it was planned that interviews with the authorities would help in collecting the required information and interviews with them would help to further specify the survey approach. It was also intended to help in finding sites and identifying the stakeholders involved, but due to their 
limited information another approach had to be developed. This led to exploration and investigation of the computer markets to identify stakeholders and sites.

As mentioned earlier, Pakistan has eight administrative units, including four provinces, and each has a capital city which is the largest city in the unit. In order to identify main e-waste recycling sites, it was deemed important to visit these capital cities. It was assumed that because they are the largest cities, they would have a significant electronics market and e-waste recycling activities. In the first field study, it was planned to visit four of these cities, along with the country's capital city of Pakistan. This included Karachi, Lahore, Peshawar and Rawalpindi/Islamabad (also called the twin city). Quetta, capital of Baluchistan, excluded from the study because of political conflicts in the region. Later on, Peshawar was also excluded due to security reasons and only Lahore, Karachi and Rawalpindi/Islamabad could be explored in field trip 1. However, Peshawar was included in field trip 2, as were several other cities, because interviews and observations in field study 1 indicated significant activities in these cities. It was learned through experience that to find sites with significant e-waste related activities, it was important to visit the local electronics markets. The sites visited were those that various stakeholders led to or mentioned in their interviews.

Field trip 1, in which data was collected for the governance analysis in Paper I, covered the three main cities where informal e-waste recycling takes place (Rawalpindi/Islamabad, Lahore and Karachi). Shadhra, a small town close to Lahore, was also included in this field study. The field trip to this town was not planned in advance, as it is not a capital city of a province or area, but interviews with the stakeholders in Lahore and their information on significant e-waste recycling activities in this town led to 
it being added as a significant site in the study. Field trip 2, in which data were collected for the SLCA in Paper II, covered seven main cities where informal e-waste recycling takes place. These were Islamabad/Rawalpindi, Lahore, Peshawar, Gujranwala, Faisalabad, Karachi and Shadhra. The sites in these cities were located using information collected through various stakeholder interviews. The interviews and sources of information that led to us finding a new site are listed in Table 1 as the source of information. The activities that were observed at these sites are also listed in Table 1. 
Table 1. Sites identified sources of information and activities seen at the recycling sites covered in field trips 1 and 2.

\begin{tabular}{|c|c|c|c|}
\hline $\begin{array}{l}\text { Field } \\
\text { trip }\end{array}$ & Sites identified & Sources of information & Activities \\
\hline 1 & $\begin{array}{l}\text { Imperial Market, } \\
\text { Rawalpindi (RWP) }\end{array}$ & First and random survey & $\begin{array}{l}\text { Buying/selling of second-hand ICT } \\
\text { equipment, scrap collection/ refurbishing. }\end{array}$ \\
\hline 1 & College Road (RWP) & $\begin{array}{l}\text { Interview with computer } \\
\text { dealers/collectors in Imperial Market } \\
\text { (RWP). }\end{array}$ & $\begin{array}{l}\text { Buying/selling of second-hand ICT } \\
\text { equipment. Manual dismantling and } \\
\text { refurbishing. }\end{array}$ \\
\hline 1 & Bhabra Bazaar (RWP) & $\begin{array}{l}\text { Interviews with scrappers at College } \\
\text { Road (RWP). }\end{array}$ & Metal extraction and selling of scrap. \\
\hline 1 & Raja Bazaar (RWP) & $\begin{array}{l}\text { Interviews conducted with dealers at } \\
\text { Imperial Market (RWP) and metal } \\
\text { extractors in Bhabra Bazaar. }\end{array}$ & $\begin{array}{l}\text { Manual dismantling of printer/e-waste. } \\
\text { Buying/selling of second-hand ICT } \\
\text { equipment. }\end{array}$ \\
\hline 1 & Dubai Plaza (RWP) & $\begin{array}{l}\text { Interviews conducted with dealers at } \\
\text { Imperial Market and scrappers and } \\
\text { dealers at College Road and Raja Bazaar. }\end{array}$ & $\begin{array}{l}\text { Buying/selling of second-hand ICT } \\
\text { equipment and refurbishing. Manual } \\
\text { dismantling of e-waste. }\end{array}$ \\
\hline 1 & $\begin{array}{l}\text { Hall Road, Lahore } \\
\text { (LHR) }\end{array}$ & $\begin{array}{l}\text { Interview conducted with NGO official in } \\
\text { Lahore. }\end{array}$ & $\begin{array}{l}\text { Buying/selling of second-hand ICT } \\
\text { equipment and refurbishing. Manual } \\
\text { dismantling and collection of e-waste. }\end{array}$ \\
\hline
\end{tabular}




\begin{tabular}{|c|c|c|c|}
\hline $\begin{array}{l}\text { Field } \\
\text { trip }\end{array}$ & Sites identified & Sources of information & Activities \\
\hline 1 & Mio Hospital (LHR) & $\begin{array}{l}\text { Interviews conducted with scrappers at } \\
\text { Hall Road. }\end{array}$ & $\begin{array}{l}\text { Selling small second-hand ICT } \\
\text { equipment/parts. }\end{array}$ \\
\hline 1 & Shalmi (LHR) & $\begin{array}{l}\text { Interviews conducted with scrappers at } \\
\text { Hall Road and metal extractors in } \\
\text { Shadhra. }\end{array}$ & $\begin{array}{l}\text { Purification and selling of precious metals } \\
\text { (not a significant site). }\end{array}$ \\
\hline 1 & Hafeez Centre (LHR) & $\begin{array}{l}\text { One of the biggest computer/electronic } \\
\text { markets in LHR. Random visit. }\end{array}$ & $\begin{array}{l}\text { Buying/selling/refurbishing of second-hand } \\
\text { ICT equipment and scrap/collection. }\end{array}$ \\
\hline 1 & Bandh Road (LHR) & $\begin{array}{l}\text { Interview with a specialist in Punjab } \\
\text { University (LHR). }\end{array}$ & Metal extraction, buying selling of e-waste. \\
\hline 1 & Township (LHR) & $\begin{array}{l}\text { Interview with a specialist in Punjab } \\
\text { University (LHR). }\end{array}$ & Recycling of batteries (not a significant site). \\
\hline 1 & Shadhra & $\begin{array}{l}\text { Interviews conducted with scrappers in } \\
\text { Hall Road (LHR). }\end{array}$ & $\begin{array}{l}\text { Buying/selling of e-waste. Manual } \\
\text { dismantling, burning of cable/e-waste and } \\
\text { precious metal extraction. }\end{array}$ \\
\hline 1 & Shershah, Karachi & $\begin{array}{l}\text { A study by Basel Action Network (BAN } \\
\text { 2002), a Greenpeace photo essay (Knoth } \\
\text { 2009), interview with officials in Pakistan }\end{array}$ & $\begin{array}{l}\text { Buying/selling of e-waste. Manual } \\
\text { dismantling, burning of cable/e-waste and } \\
\text { precious metal extraction. }\end{array}$ \\
\hline
\end{tabular}




\begin{tabular}{|c|c|c|c|}
\hline Field & Sites identified & Sources of information & Activities \\
\hline & & $\begin{array}{l}\text { Environmental Protection Agency } \\
\text { (PEPA), and an interview with a dealer at } \\
\text { Raja Bazaar (RWP). }\end{array}$ & \\
\hline 2 & $\begin{array}{l}\text { Rawalpindi/ } \\
\text { Islamabad }\end{array}$ & $\begin{array}{l}\text { Some officials were interviewed in } \\
\text { Islamabad but Islamabad electronic } \\
\text { market was not covered in the previous } \\
\text { field trip so was explored in the second } \\
\text { field trip. In Rawalpindi, the same sites } \\
\text { were visited }\end{array}$ & $\begin{array}{l}\text { Buying/selling of second-hand ICT } \\
\text { equipment and collection of e-waste seen in } \\
\text { Islamabad. }\end{array}$ \\
\hline 2 & Lahore & $\begin{array}{l}\text { Same sites were visited as identified in } \\
\text { previous study and had significant } \\
\text { activity. }\end{array}$ & $\begin{array}{l}\text { Buying/selling/refurbishing of second-hand } \\
\text { ICT equipment and scrap/collection and } \\
\text { manual dismantling. }\end{array}$ \\
\hline 2 & Shadhra & $\begin{array}{l}\text { Detailed study of the village based on } \\
\text { previous field trip. }\end{array}$ & $\begin{array}{l}\text { Manual dismantling, burning of cable/e-waste } \\
\text { and precious metal extraction, purification of } \\
\text { precious metals. }\end{array}$ \\
\hline 2 & Faisalabad & $\begin{array}{l}\text { Interview with a business owner of } \\
\text { precious metal extractor met at Dubai }\end{array}$ & $\begin{array}{l}\text { Manual dismantling, refurbishing and semi- } \\
\text { formal metal extraction. }\end{array}$ \\
\hline
\end{tabular}




\begin{tabular}{|l|l|l|l|}
\hline $\begin{array}{l}\text { Field } \\
\text { trip }\end{array}$ & Sites identified & Sources of information & Activities \\
\hline 2 & Gujranwala & $\begin{array}{l}\text { Plaza (RWP) during field trip 1. } \\
\text { Road, Dubai Plaza during the first field } \\
\text { trip. }\end{array}$ & $\begin{array}{l}\text { Buying/selling of e-waste. Manual } \\
\text { dismantling and refurbishing. }\end{array}$ \\
\hline 2 & Peshawar & $\begin{array}{l}\text { Random visit based on being capital of } \\
\text { KPK province and a transit route to } \\
\text { Afghan imports and Chinese imports. }\end{array}$ & $\begin{array}{l}\text { Buying/selling of e-waste/second-hand ICT } \\
\text { equipment, refurbishing and manual } \\
\text { dismantling, }\end{array}$ \\
\hline 2 & Karachi & $\begin{array}{l}\text { Visit to Shershah, Karachi, which was } \\
\text { identified in field trip 1. }\end{array}$ & $\begin{array}{l}\text { Buying/selling of e-waste. Manual } \\
\text { dismantling, burning of cable/e-waste and } \\
\text { precious metal extraction. }\end{array}$ \\
\hline
\end{tabular}


All possible stakeholders were identified and interviewed to collect data.

\subsubsection{Field trip 1}

The aim of field trip 1 was to:

- Map flows of e-waste to and within Pakistan.

- Identify the main recycling sites in Pakistan.

- Identify the main stakeholders in e-waste recycling in Pakistan.

- Study the structure of the informal e-waste recycling business.

- Understand the process of informal e-waste recycling.

- Highlight possible social, health and environmental impacts of informal e-waste recycling.

- Examine governance issues of the informal e-waste recycling business.

The information was collected through interviews with various stakeholders, observation of the recycling sites and activities, and studying relevant official documents. The interviews were documented in the form of written notes, photographs were taken of the sites and stakeholders, and in some cases short videos were also made of the ewaste recycling processes. This information was interpreted and findings were further verified through a supporting literature review. It was also seen that there was some similarity in the processes, information across the country and information gathered and documented in studies conducted in other developing countries. The respondents or stakeholders that were interviewed were selected on the basis of convenience sampling, i.e. they showed willingness to be interviewed, and 
on the basis of their role in the e-waste recycling business. It was ensured that all the respondents interviewed were directly/indirectly involved in the business. All stakeholders apart from a few were mostly enthusiastic and willing to be interviewed and therefore efforts were made to interview as many people as possible in order to gather the maximum amount of information. Details of interviews conducted during field trip 1 are listed in Table 2.

Table 2. Stakeholders identified and interviewed at sites visited in field trip 1.

\begin{tabular}{|c|c|c|}
\hline Sites & Stakeholders identified and interviewed & $\begin{array}{l}\text { Total no. of } \\
\text { interviews }\end{array}$ \\
\hline $\begin{array}{l}\text { At the official } \\
\text { level }\end{array}$ & $\begin{array}{l}\text { Government officials at the Ministry of } \\
\text { Environment (3), non-governmental } \\
\text { organisation (NGO) officials (4), Pakistan } \\
\text { Environmental Protection Agency (PEPA) (2), } \\
\text { experts (3), Bureau of Statistics (2), State Bank } \\
\text { of Pakistan (1), customs officers (5) }\end{array}$ & 20 \\
\hline $\begin{array}{l}\text { Imperial } \\
\text { Market } \\
\text { (RWP) }\end{array}$ & ICT equipment dealers (8), collectors (2) & 10 \\
\hline $\begin{array}{l}\text { College Road } \\
\text { (RWP) }\end{array}$ & $\begin{array}{l}\text { Scrapers (10), ICT equipment dealers (10), } \\
\text { refurbishers (4) }\end{array}$ & 24 \\
\hline $\begin{array}{l}\text { Bhabra } \\
\text { Bazaar(RWP) }\end{array}$ & $\begin{array}{l}\text { E-waste/scrap dealers (5), precious metal } \\
\text { extractors (8), jewellers/ business owners (2). }\end{array}$ & 15 \\
\hline $\begin{array}{l}\text { Dubai Plaza } \\
\text { (RWP) }\end{array}$ & $\begin{array}{l}\text { ICT equipment dealers (5), refurbishers (4), } \\
\text { business owners (2), scrappers (12), precious } \\
\text { metal extractors (2). }\end{array}$ & 25 \\
\hline Raja Bazaar & Business owners (3), scrappers (9). & 11 \\
\hline
\end{tabular}




\begin{tabular}{|c|c|c|}
\hline Sites & Stakeholders identified and interviewed & $\begin{array}{l}\text { Total no. of } \\
\text { interviews }\end{array}$ \\
\hline \multicolumn{3}{|l|}{ (RWP) } \\
\hline $\begin{array}{l}\text { Hall Road } \\
\text { (LHR) }\end{array}$ & $\begin{array}{l}\text { ICT equipment dealers (10), scrappers (12), } \\
\text { business owners (5), collectors (3) }\end{array}$ & 30 \\
\hline $\begin{array}{l}\text { Mio Hospital } \\
\text { (LHR) }\end{array}$ & Dealers (8). & 8 \\
\hline $\begin{array}{l}\text { Hafeez Center } \\
\text { (LHR) }\end{array}$ & ICT equipment dealers (6), importers (5) & 11 \\
\hline $\begin{array}{l}\text { Bandh } \\
\text { Road(LHR) }\end{array}$ & Metal extractors (2), dealers (2) & 4 \\
\hline $\begin{array}{l}\text { Township } \\
\text { (LHR) }\end{array}$ & Scrapers/recyclers (6). & 6 \\
\hline Shalmi (LHR) & $\begin{array}{l}\text { Precious metal purifiers (niharye) (6), jewellers } \\
\text { (8) }\end{array}$ & 14 \\
\hline Shadhra & $\begin{array}{l}\text { Business owners (2), scrappers (5), cable/e- } \\
\text { waste burners (4), computer dealers (2). }\end{array}$ & 13 \\
\hline $\begin{array}{l}\text { Shershah, } \\
\text { Karachi }\end{array}$ & Dealers (10), scrappers (20), importers (8) & 38 \\
\hline
\end{tabular}

\subsubsection{Field trip 2}

Field trip 2 was conducted in order to:

- Identify informal recycling sites in other cities than those visited in field trip 1.

- Study the social impacts of the informal e-waste recycling business in Pakistan.

Data were collected through interviews, observations and analysis of relevant documents. The information collected in interviews was documented in written form and through audio recordings. Video recordings and photographs were also taken. The respondents in field trip 
2 were again selected on the basis of their relevance to the stakeholder categories studied and their willingness to respond/contribute. A scientific and policy-related literature review was conducted to further verify the findings. These data were assessed within the SLCA framework, as described in section 5.4, to assess the social impacts of the e-waste recycling business. This led to the development of Paper II. Details of stakeholders and interviews conducted are presented in Table 3.

Table 3. Stakeholders identified and interviewed at sites visited in field trip 2.

\begin{tabular}{|l|l|l|}
\hline Sites & Stakeholders identified and interviewed & $\begin{array}{l}\text { Total no. of } \\
\text { interviews }\end{array}$ \\
\hline $\begin{array}{l}\text { At official } \\
\text { level }\end{array}$ & $\begin{array}{l}\text { Government officials at the Ministry of } \\
\text { Environment (1), non-government organisation } \\
\text { (NGO) officials (1), Pakistan Environmental } \\
\text { Protection Agency (PEPA) (2), experts (1), customs } \\
\text { officers (8). }\end{array}$ & 13 \\
\hline Islamabad & $\begin{array}{l}\text { ICT equipment dealers (15), refurbishers (5), } \\
\text { collectors (6). }\end{array}$ & 26 \\
\hline $\begin{array}{l}\text { Rawalpind } \\
\text { i }\end{array}$ & $\begin{array}{l}\text { ICT equipment dealers (8), refurbishers (4), } \\
\text { business owners (5), scrappers (41), local } \\
\text { community (6). }\end{array}$ & 64 \\
\hline Lahore & $\begin{array}{l}\text { ICT equipment dealers (20), business owners (4), } \\
\text { scrappers (30), local community (5), precious metal } \\
\text { extractor (2). }\end{array}$ & 61 \\
\hline Shadhra & $\begin{array}{l}\text { Business owner (5), scrappers (25), cable/e-waste } \\
\text { burners (10), precious metal extractors (2), local } \\
\text { community (6). }\end{array}$ & 48 \\
\hline $\begin{array}{l}\text { Gujranwal } \\
\text { a }\end{array}$ & $\begin{array}{l}\text { Business owners (5), scrappers (20), e-waste dealer } \\
\text { (1). }\end{array}$ & 26 \\
\hline Faisalabad & $\begin{array}{l}\text { Business owners (10), scrappers (18), metal } \\
\text { extractors (4), local community (3). }\end{array}$ & 35 \\
\hline Peshawar & Business owner (10), scrappers (8). & 18 \\
\hline Karachi & $\begin{array}{l}\text { Business owners (6), scrappers (14), cable/e-waste } \\
\text { burners (1), precious metal extractors (3), precious } \\
\text { metal purifiers (3). }\end{array}$ & 27 \\
\hline
\end{tabular}




\subsection{Data collection through questionnaire and interviews}

Due to lack of existing data on the subject of informal e-waste recycling in Pakistan, empirical data had to be collected. For this purpose, interviews were conducted and open ended questionnaires were developed. For field trip 1, the interviews focused on an overview of the business. These interviews were based on open-ended questions to gather general and maximum information about the business and its mechanisms. Some of the questions developed for field trip 1 are listed in Table 4.

Table 4. Questions developed for the interviews conducted in field trip 1.

\begin{tabular}{|c|c|}
\hline Stakeholder & Questions/issues discussed \\
\hline $\begin{array}{l}\text { Government } \\
\text { and NGO } \\
\text { officials, } \\
\text { Pakistan } \\
\text { Environmental } \\
\text { Protection } \\
\text { Agency } \\
\text { (PakEPA) }\end{array}$ & $\begin{array}{l}\text { - Is informal e-waste recycling taking place in } \\
\text { Pakistan? } \\
\text { - What do you know about the business? } \\
\text { - Howe is it taking place? } \\
\text { - Are there any exisinting regulations regarding the } \\
\text { business? } \\
\text { - How much e-waste comes to Pakistan and what are } \\
\text { the source countries? } \\
\text { - What are the government initiatives to control this } \\
\text { business? }\end{array}$ \\
\hline $\begin{array}{l}\text { Bureau of } \\
\text { Statistics and } \\
\text { State Bank of } \\
\text { Pakistan }\end{array}$ & - $\quad$ Details of imports, quantities etc. \\
\hline $\begin{array}{l}\text { Customs } \\
\text { officers }\end{array}$ & $\begin{array}{l}\text { - How does e-waste arrive in Pakistan? } \\
\text { - How does it enter the country? } \\
\text { - Is there a coding system for e-waste? } \\
\text { - } \text { shat happens if it is not second-hand items and just } \\
\text { - How much e-waste is received in Pakistan? } \\
\text { - Is there any legislation regarding e-waste? } \\
\end{array}$ \\
\hline Importers & $\begin{array}{l}\text { - How is e-waste sold in the market? } \\
\text { - What is its life after reaching Pakistan? } \\
\text { - How is it bought in from abroad? } \\
\text { - What are the source countries? }\end{array}$ \\
\hline
\end{tabular}




\begin{tabular}{|c|c|}
\hline Stakeholder & Questions/issues discussed \\
\hline & $\begin{array}{l}\text { - Who are the buyers? } \\
\text { - Do you know where e-waste is recycled informally } \\
\text { in Pakistan? }\end{array}$ \\
\hline $\begin{array}{l}\text { ICT equipment } \\
\text { dealers }\end{array}$ & $\begin{array}{l}\text { - How and from whom you buy equipment? } \\
\text { - What is the life span of this equipment? } \\
\text { - What happen if it is completely scrap? } \\
\text { - What happens to scrap? } \\
\text { - Where are the scrappers? } \\
\text { - What is the demand for this equipment? } \\
\text { in Pakistan? }\end{array}$ \\
\hline $\begin{array}{l}\text { Scrappers, } \\
\text { dismantlers, } \\
\text { metal } \\
\text { extractors, } \\
\text { collectors }\end{array}$ & $\begin{array}{l}\text { - } \quad \text { What are the prices paid for e-waste? } \\
\text { - } \quad \text { How long have you been in the business? } \\
\text { - } \quad \text { Why do you work in this business? } \\
\text { - } \quad \text { Have you experienced any ailments as a result of this } \\
\text { business? } \\
\text { - What can be done to improve your working } \\
\text { - } \quad \text { What is the level of awareness among workers? } \\
\text { - } \quad \text { How are the processes involved carried out? } \\
\text { - What work-related precautions do you take? } \\
\text { - What prices are paid for materials extracted, who are } \\
\text { the buyers, what are the profit margins? } \\
\text { recycling? }\end{array}$ \\
\hline $\begin{array}{l}\text { Precious metal } \\
\text { purifier }\end{array}$ & - What is the process of precious metal purification? \\
\hline Jewellers & $\begin{array}{l}\text { - Where do you buy e-waste from? } \\
\text { - Who extracts the precious metals for you? } \\
\text { - What are the costs/profits? } \\
\text { - Why do you work in this business? }\end{array}$ \\
\hline
\end{tabular}

The questionnaire used for field trip 2 was structured based on openended interviews (Table 5). This questionnaire was developed using the subcategories and stakeholder categories defined by the UNEP SETAC Guidelines for SLCA (cf. section 5.4). The questionnaire was intended to explore the social impacts of the e-waste recycling business. 
Table 5. Questions developed for the interviews conducted in field trip 2.

\begin{tabular}{|c|c|}
\hline Stakeholder & Questions \\
\hline Workers & 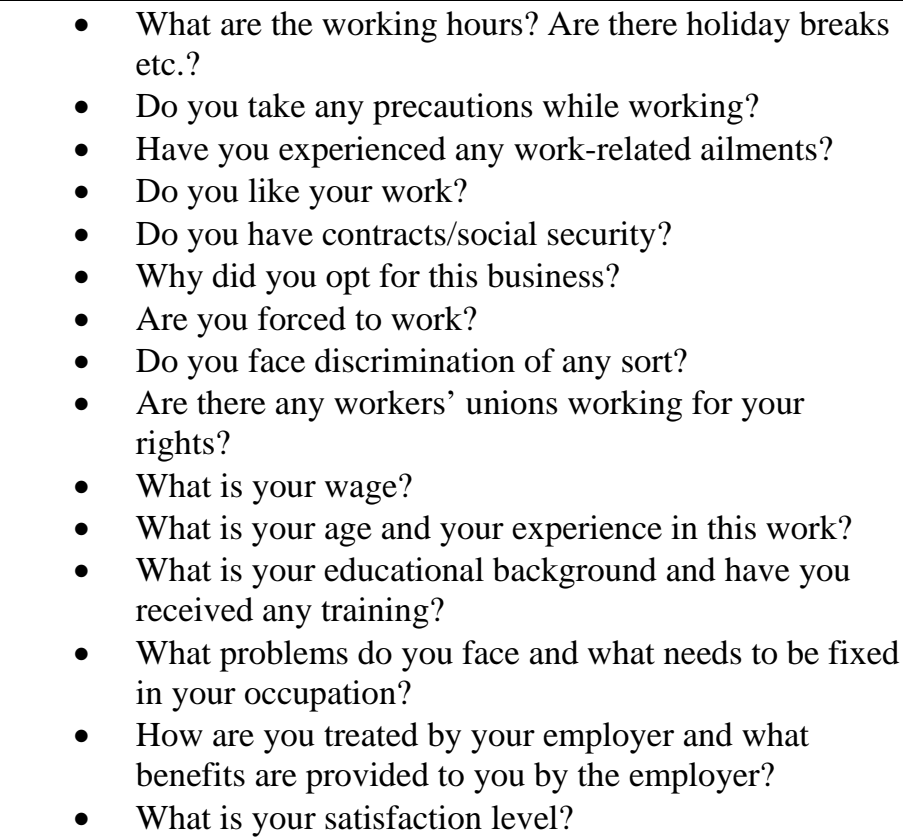 \\
\hline $\begin{array}{l}\text { Local } \\
\text { community }\end{array}$ & $\begin{array}{l}\text { - How are you affected by these work activities? } \\
\text { - Are there any ailments you can attribute to the } \\
\text { business? } \\
\text { - Has any development/improvement initiative been } \\
\text { taken by owner or workers or government/NGO? } \\
\text { - What is the extent of government involvement in the } \\
\text { community? }\end{array}$ \\
\hline $\begin{array}{l}\text { Value chain } \\
\text { actors }\end{array}$ & $\begin{array}{l}\text { - Are you aware regarding the impacts of your business? } \\
\text { - Do you share awareness about your business with your } \\
\text { - Horker/community? } \\
\text { - Has any initiative been taken by you for the } \\
\text { - Has efforts been made to improving the working } \\
\text { conditions/environment? } \\
\text { - Who/ what controls the market? } \\
\text { - Prices and profits. }\end{array}$ \\
\hline
\end{tabular}




\subsection{Governance analysis}

Informal refers to being beyond the reach of different levels and mechanisms of official governance, lacking in regulation, structure and institutionalisation, and being non-registered and illegal (Chi et al., 2011). Understanding the character of an informal business requires an assessment of underlying governance weaknesses that enable such an activity to continue. In order to carry out an analysis of the roles of actors, the type of government and the dynamics of this system, we used the diagram of the informal e-waste recycling business shown in Figure 2 to structure our findings for different stages through the process. This structure of informal recycling business has been shown to exist in other developing countries (Chi et al., 2011) and a similar process has been observed in Shershah Karachi (BAN, 2002).

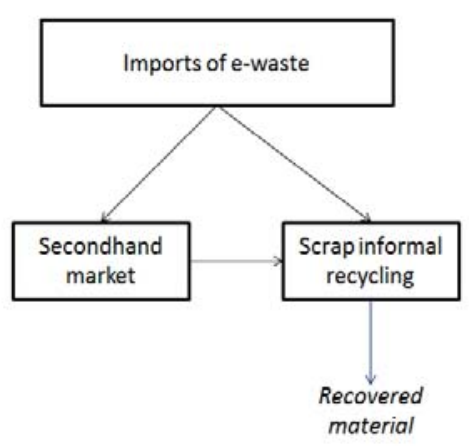

Figure 2 General sketch of the informal e-waste recycling business.

The flow chart in Figure 2 acted as a guide to structure the information obtained in field studies about the e-waste business in Pakistan. This provided a rough sketch of e-waste entering Pakistan: after being sorted at the second-hand market, the e-waste enters the informal recycling sector and follows the process of e-waste recycling described previously 
by Chi et al. (2011). As part of the present study, we needed to identify the market mechanisms, how e-waste enters Pakistan and the informal chains and stakeholders involved in this process.

Governance addresses how decisions are made and implemented in different contexts, how power is exercised and distributed, and whether and how citizens participate in decision making. The use of governance implies that power is not only exercised by hierarchical formal authorities, but also by markets and networks, and that other actors in many ways influence steering processes in society. Analysing governance of any activity, including informal recycling, makes it important to understand the roles of actors, prevalent types of governance system and their mutual relations under the existing conditions (Sutinen et al., 2000; Bartle et al. 2012).

The hybrid governance structure proposed by Lemos and Agrawal (2006) was used to assess the current status of the informal e-waste recycling business in Pakistan and highlight the role of the stakeholders. The application of good governance results in better management of an activity. In order to assess the governance weaknesses which lead to inability to achieve good governance in the informal e-waste recycling business in Pakistan, we assessed the whole informal recycling system under the four pillars of good governance as defined by WorldBank (WorldBank, 1999). These four pillars are accountability, transparency, rule of law and participation.

\subsection{Social Life Cycle Assessment (SLCA)}

Social Life Cycle Assessment is a tool that can be used to assess the social impacts of a product or service over its lifetime. It assesses the positive and negative impacts of a product or service from extraction through 
processing of raw material, manufacturing, distribution, use-reuse, maintenance and recycling to final disposal (Benoît and Mazijn, 2009). It is conducted using UNEP methodological guidelines developed according to the ISO 14040 and 14044 standards (ibid). SLCA is based on generic or site-specific data in relation to product processes and covers the impacts of these processes on the various stakeholders involved along the supply chain.

SLCA is usually conducted in order to assess the social impacts and highlight negative impacts of a process for the information of the relevant stakeholders and in order to improve these impacts. It does not provide grounds for deciding whether the product should be produced or not.

According to the UNEP guidelines, the goal of SLCA is to assess impacts on the Area of Protection (AoP). In SLCA, the AoP is human wellbeing and all impacts are studied in reference to this. Stakeholders and impact categories are selected to assess how human wellbeing may be affected in the life cycle of a product. SLCA includes selection of relevant stakeholders, subcategories and impact categories.

\section{Functional unit}

In order to conduct an SLCA, the first step is to define the functional unit of the product system. In the case of semi-quantitative and qualitative data, the impacts are not necessarily expressed per functional unit.

\section{System boundaries}

In SLCA, it is important to define the boundaries of the system in order to delineate and determine which processes are to be included in the system and which are to be excluded from the system. Some SLCAs are dependent on site-specific data and therefore it is important to mark the 
geographical boundaries of the study. It is also important to specify the organisations and stakeholders involved in the process and who should be included/excluded from the system during the analysis. It is also important to inform the audience about whether the underlying data used were generic or site-specific. The subjectivity and uncertainty related to this assessment should be clearly mentioned.

\section{Inventory data collection}

For inventory data collection, it is first necessary to select the subcategories. Subcategory in SLCA is the social or socio-economic issue of concern (Benoit and Mazijn, 2009). Once the subcategories have been selected and the stakeholders decided, the data can be collected. These data can be generic, based on national, international or sector data, but site-specific data are always preferable (J orgensen et al., 2008). Such data are usually collected through interviews and questionnaires on-site. Methodological worksheets developed in connection with the UNEP/SETAC guidelines can help to define the subcategories and identify sources that can be used to collect data in reference to these subcategories.

\section{Impact assessment}

The impact assessment process includes selection of impact categories and methods/models for the presentation of results. It involves classification, where inventory data are related to subcategories and impact categories, and characterisation, where the results for the subcategory indicators are calculated (Benoît and Mazijn, 2009). There is no specific way of conducting and presenting impact assessments in SLCA. In this thesis, the simple colour-based assessment method devised by Ciroth and Franze (2011) was used. 


\section{Summary of results}

Both papers included in this thesis provide new information describing the status of the informal e-waste recycling business in Pakistan. The presentation of results in this chapter is organised according to research questions Q1-Q4 as outlined in Chapter 2 along with the aims of the thesis and of Papers I and II.

\section{Q1. What is the current situation of informal e-waste recycling in Pakistan?}

In order to study the current status of the informal e-waste recycling business in Pakistan, it was necessary to identify the sources and international/national flows of e-waste, the mechanisms of the e-waste business and the process of informal e-waste recycling. This was addressed in Paper I.

It was found through interviews with dealers and importers that e-waste imports to Pakistan originate from, among other countries, USA, EU, United Arab Emirates (UAE), Singapore and Africa (Paper I). The majority of these source countries have in one form or another some sort of Extended Producer Responsibility (EPR) or collection and recycling programmes, yet e-waste still manages to escape the formal system and enter the informal recycling trade. At the same time, Pakistan is a signatory to the Basel Convention and has other national legislation regarding e-waste, yet e-waste makes its way into the country. During the field trip for Paper I, interviews with the importers and one government official showed that most e-waste manages to enter Pakistan camouflaged as second-hand equipment/ charity/transit imports for Afghanistan, but at times is also smuggled from UAE. When e-waste enters Pakistan, it is 
usually mislabelled and therefore it is easily overlooked by authorities and customs checks. Internationally, import and export commodities are identified by their codes. In the case of electronics, the code is the same for both new equipment and waste, which leads to easier transboundary movement of e-waste.

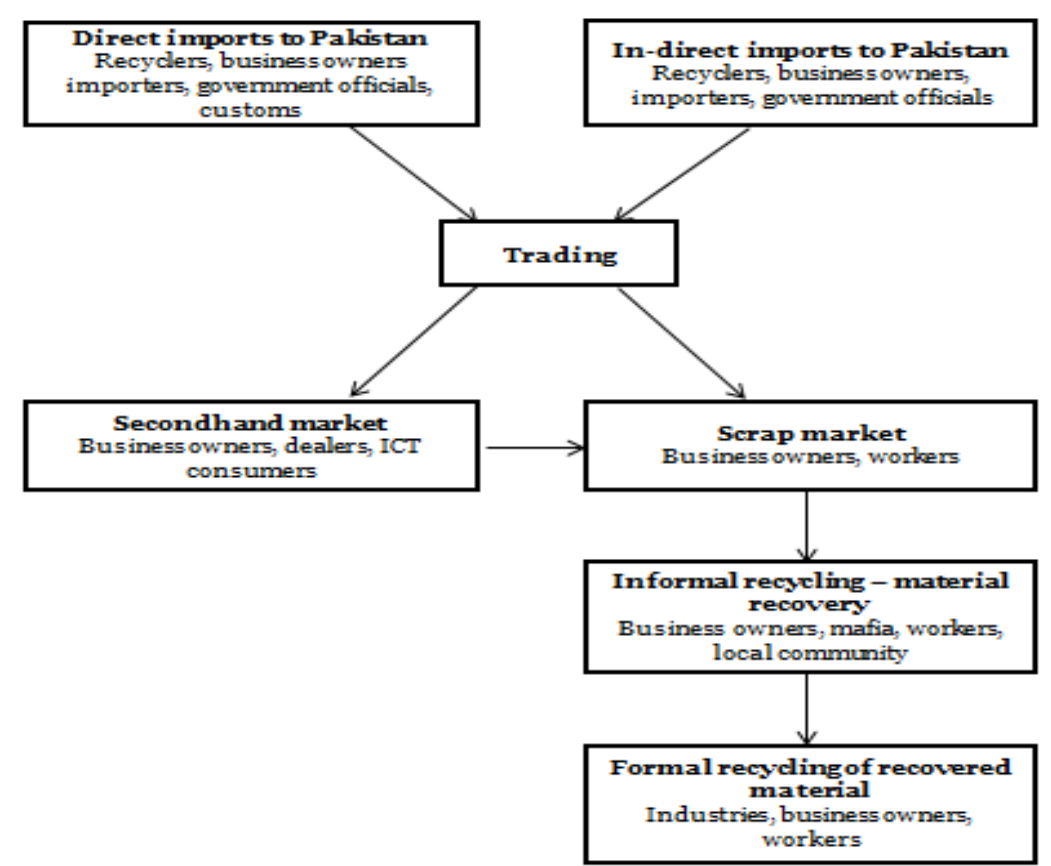

Figure 3 Structure of the e-waste business in Pakistan (Paper I).

Figure 3, which is one of the main outcomes of Paper I, provides an overview of the current situation in terms of the flow of e-waste and stakeholders involved in informal recycling of e-waste in Pakistan.

The import of e-waste flourishes because of the increasing demand and dependence of Pakistan's population on cheap ICT equipment. As the 
price of e-waste or second-hand equipment is lower, it provides access to ICT equipment among the population of Pakistan that cannot afford to buy new ICT products at full price. Various stakeholders are involved in this business, from import to recycling.

When the products are imported, the importers are unaware of its quality (whether it is reusable or completely junk). Equipment is bought in bulk from abroad and the same price is paid for equipment that might be $\mathrm{e}$ waste or second-hand equipment. In order to get the same amount of return on their purchase, importers impose an extra fee for dealers who want to check the equipment before buying. Thus the dealers face uncertainty when buying equipment without checking it beforehand, and are either forced to pay the fee for checking it or risk buying faulty equipment that cannot be resold, resulting in a loss to the dealer.

There is a lack of knowledge among authorities and import officers in Pakistan regarding e-waste imports and the informal recycling business and its impacts. Moreover, consignments of e-waste usually come camouflaged as safe equipment, with certification confirming that it is in line with the Basel Convention, making the trade difficult to control.

As there is no EPR programme or formal recycling facilities operating in Pakistan, any ICT products that have no resale and reuse value eventually end up in the informal recycling stream. Here the e-waste is collected and manually dismantled. The dismantled parts are then sold to various stakeholders such as metal extractors, recyclers etc. Most of the components are extracted and recycled. Plastics, gold, silver, copper and aluminium are the most sought-after materials. Apart from manual dismantling, informal recycling also involves burning of wire for extraction of copper, toner sweeping to extract aluminium, acid dipping 
and burning of printed wire boards to extract precious metals. However, the burning of plastic releases dioxin and furans into the air; toner ink and ash from plastic is left on the ground to pollute groundwater and nearby water bodies; and used acid is dumped into nearby water bodies. This improper handling of e-waste leads to air, soil and water pollution and harms the workers involved in the business. Moreover, since the recycling activities usually take place in populated areas, they also threaten the health of the people living in the vicinity of these sites. There are also social impacts of the business. However, little expertise is required for the work, there is easy access to waste and profit margins are high, which are the main reasons why informal e-waste recycling has become such a successful business in Pakistan.

\section{Q2. Who are the important stakeholders and what are their roles in this business?}

Various stakeholders are involved in the informal e-waste recycling business. Their roles and involvement were sketched out in Paper I and are summarised in Figure 4. These stakeholders include importers, exporters, buyers, sellers, the general population of Pakistan, scrappers, collectors, brokers and metal extractors. Women and children are equally involved in the recycling business. Figure 4 summarises these stakeholders in relation to the processes in which they are involved. 


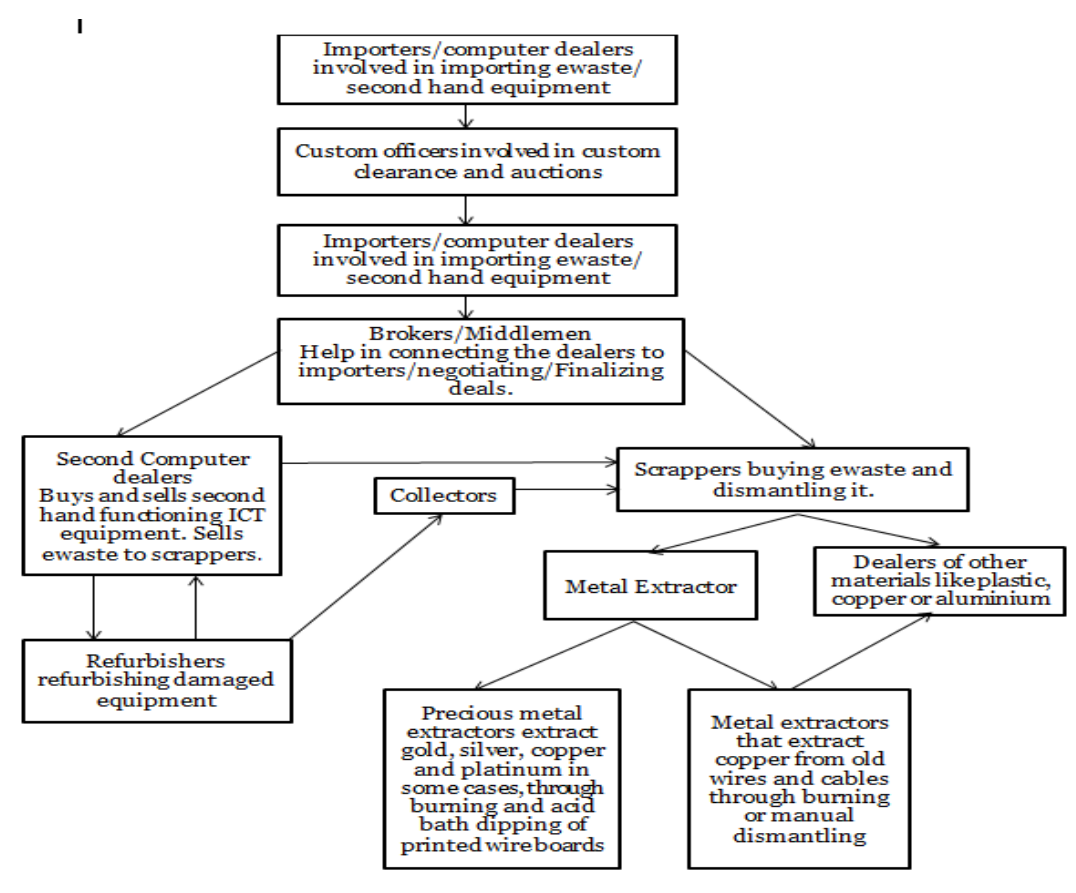

Figure 4 Stakeholders involved in the informal e-waste recycling business in Pakistan and their specific roles.

In the informal recycling business, it was found that all the stakeholders have defined roles. For example, scrappers are involved solely in manual dismantling and they do not participate in metal extraction. This results in a semi-formalised chain of stakeholders with a very well defined and structured set of roles. A number of important stakeholders, such as government, NGOs and producers of ICT equipment, were found not to be involved in the sector. One important stakeholder benefiting from the e-waste business is the local mafia in Karachi. They control the market in this area. They also control the prices of e-waste (they are kept low), so that the mafia can ensure good profit margins as the prices of precious 
metals increase globally. The full stakeholder analysis, which is presented in Paper I, provided the baseline for Paper II.

In Paper II, the stakeholders identified were divided into four categories to assess the social impacts of the informal e-waste recycling business. These categories were: workers (scrappers, metal extractors, collectors and refurbishers), the local community (people living in the vicinity of recycling sites), society (the general population of Pakistan) and value chain actors (business owners, mafia).

\section{Q3. What are the governance issues enabling this business?}

Despite various legislative mechanisms being in place, the informal ewaste recycling sector in Pakistan has been growing and has resulted in economic, social and environmental impacts. The stakeholder analysis and interviews with the various stakeholders in Papers I and II led to a better understanding of various governance issues prevailing in the business.

Most e-waste is shipped from developed countries to Pakistan. One reason for this is that despite the high collection rates and better formal recycling facilities in developed countries, it is cheaper to recycle e-waste in Pakistan. Another reason is that there is weaker implementation of legislation regarding imports of e-waste and informal recycling in Pakistan. The existing legislative structure for prevention of these e-waste flows may not be effective due to mislabelling of the equipment involved, Basel Convention certification accompanying the consignments (as some exporters are able to provide certificates for the products involved), lack of knowledge among the authorities and loopholes and losses in the 
developed countries. The lack of transparency and lack of awareness among the authorities make it difficult to control these flows.

One of the reasons of why e-waste enters Pakistan and the reason for these global flows in general is due to weakness of Extended Producer Responsibility (EPR) programmes in the developed countries and at source. The majority of the e-waste collected in the western USA and Europe for recycling goes into hidden flows and most of it ends up in informal recycling chains in developing countries. These exports could be reduced significantly if the producers monitored where their products ended up at the EoL and how they are managed. There is also a lack of EPR and formal recycling facilities in Pakistan, which leads to flows of ewaste into the informal chains. Better implementation of EPR in developed countries and its introduction in Pakistan might help in improving this situation.

There are huge numbers of stakeholders along the chain of the informal e-waste recycling business, starting from the developed countries and ending up at the recycler in Pakistan. Many of these stakeholders depend on this business as their sole source of livelihood, which therefore it makes it challenging to control or stop the business. In the case of informal recycling, this is carried out by a vulnerable class of individuals that includes children, women and men who have no other source of income. They mostly belong to the class living below the poverty line. The profitability of the e-waste recycling business attracts them into carrying out toxic procedures.

Some important stakeholders are currently missing from the e-waste recycling business chain. They are stakeholders who could play a vital role in improvement of the business, such as the government, NGOs and ICT 
companies. The lack of awareness and initiative on their behalf makes it difficult to control the e-waste recycling business and its impacts.

The growing dependence of the population of Pakistan on second-hand ICT product leads to more inflows of these items, making it difficult to stop these imports and the business as a whole.

Q4. What are the social impacts for individuals and society arising from this business?

Paper I described the process of informal e-waste recycling in Pakistan and identified the stakeholders involved. This provided the platform for Paper II, which assessed the social impacts of informal recycling using the UNEP/ SETAC SLCA methodology guidelines. 


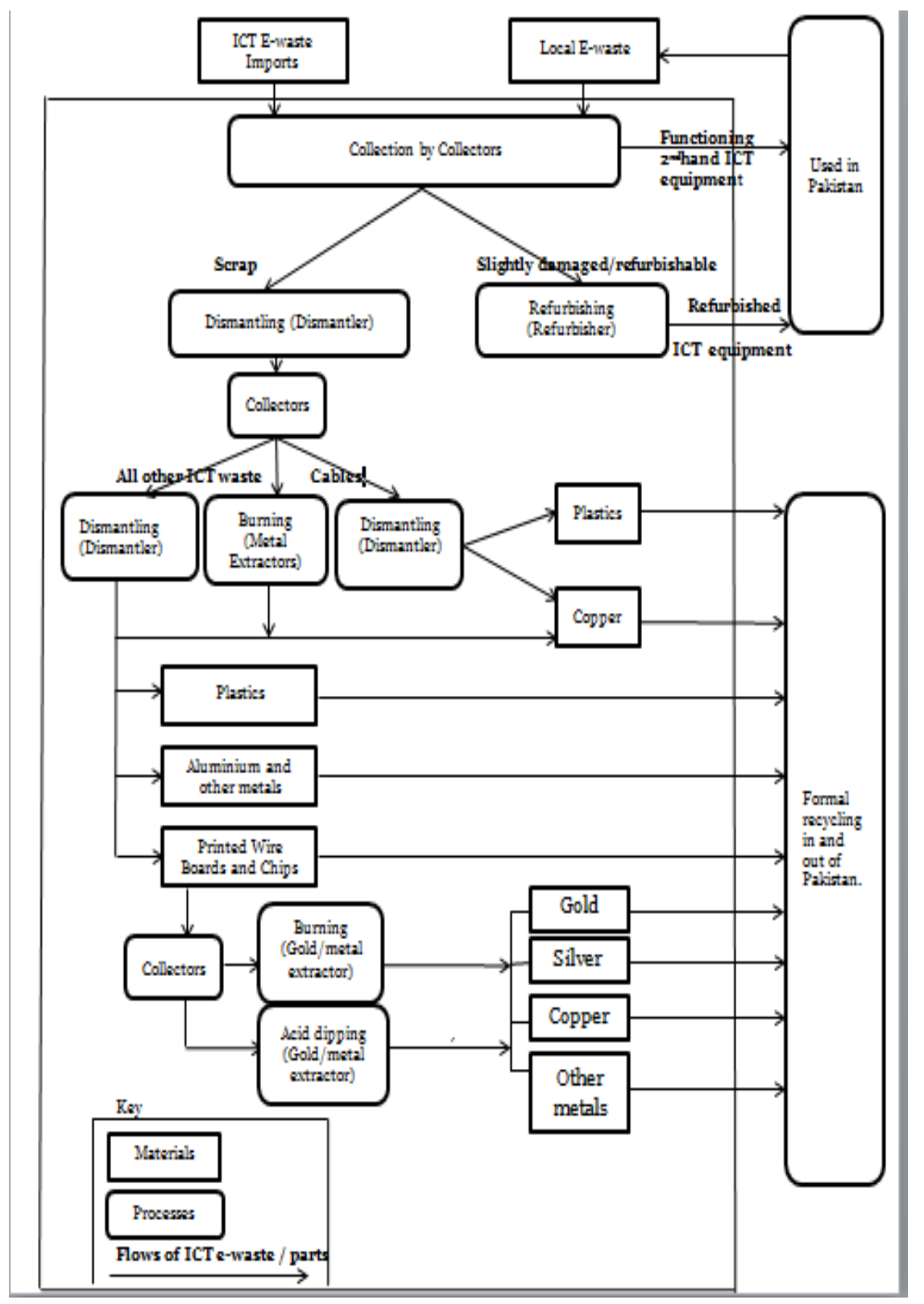

Figure 5 Informal e-waste recycling in Pakistan with system boundaries defined in Paper II. 
The flow chart developed in Paper I was further elaborated in Paper II in terms of a detailed overview of material/product flows, processes and stakeholders (Figure 35). The diagram also shows the system boundaries of this SLCA.

In Paper II, data were collected on the social impacts of informal e-waste recycling on the stakeholders involved. Existing standards and legislation were studied to assess the compliance with these subcategories and develop the inventory analysis.

The inventory analysis confirmed the expected negative social impacts of this business, although a couple of positive impacts were also identified, as summarised in

Table 6.

Table 6. Summary of the social impact assessment conducted in Paper II

\begin{tabular}{|c|c|c|c|c|c|c|c|}
\hline & & & & \multicolumn{4}{|c|}{ Impact category } \\
\hline $\begin{array}{l}\text { Stakeholder } \\
\text { category }\end{array}$ & Subcategory & $\begin{array}{l}\text { Status in } \\
\text { summary }\end{array}$ & $\begin{array}{l}\text { Performance } \\
\text { assessment }\end{array}$ & $\begin{array}{l}\text { Health \& } \\
\text { safety } \\
\text { (impact) }\end{array}$ & $\begin{array}{l}\text { Socio- } \\
\text { eco } \\
\text { repercus } \\
\text { sion }\end{array}$ & $\begin{array}{l}\text { Human } \\
\text { rights }\end{array}$ & $\begin{array}{l}\text { Dev. of } \\
\text { country }\end{array}$ \\
\hline \multirow[t]{6}{*}{ Worker } & $\begin{array}{l}\text { Working } \\
\text { Hours }\end{array}$ & 74 hrs. + & & $\checkmark$ & $\checkmark$ & $\checkmark$ & NA \\
\hline & Child labour & Yes & & NA & NA & $\checkmark$ & $\checkmark$ \\
\hline & $\begin{array}{l}\text { Health and } \\
\text { safety (work } \\
\text { environment) }\end{array}$ & $\begin{array}{l}\text { Extensive } \\
\text { negative } \\
\text { impacts }\end{array}$ & & $\checkmark$ & $\checkmark$ & $\checkmark$ & $\checkmark$ \\
\hline & $\begin{array}{l}\text { Social } \\
\text { security }\end{array}$ & No & & NA & $\checkmark$ & $\checkmark$ & NA \\
\hline & Forced labour & Not seen & & NA & NA & & NA \\
\hline & Wages & $\begin{array}{l}\text { More } \\
\text { than } \\
\text { USD } \\
\text { 2.7/day }\end{array}$ & & NA & NA & & \\
\hline
\end{tabular}




\begin{tabular}{|c|c|c|c|c|c|c|c|}
\hline \multirow[b]{2}{*}{$\begin{array}{l}\text { Stakeholder } \\
\text { category }\end{array}$} & \multirow[b]{2}{*}{ Subcategory } & \multirow[b]{2}{*}{$\begin{array}{l}\text { Status in } \\
\text { summary }\end{array}$} & \multirow[b]{2}{*}{$\begin{array}{l}\text { Performance } \\
\text { assessment }\end{array}$} & \multicolumn{4}{|c|}{ Impact category } \\
\hline & & & & $\begin{array}{l}\text { Health \& } \\
\text { safety } \\
\text { (impact) }\end{array}$ & $\begin{array}{l}\text { Socio- } \\
\text { eco } \\
\text { repercus } \\
\text { sion } \\
\end{array}$ & $\begin{array}{l}\text { Human } \\
\text { rights }\end{array}$ & $\begin{array}{l}\text { Dev. of } \\
\text { country }\end{array}$ \\
\hline & $\begin{array}{l}\text { Equal } \\
\text { opportunity/di } \\
\text { scrimination }\end{array}$ & $\begin{array}{l}\text { Equal } \\
\text { opportuni } \\
\text { ties, no } \\
\text { discrimin } \\
\text { ation }\end{array}$ & & NA & NA & & \\
\hline & $\begin{array}{l}\text { Freedom of } \\
\text { association }\end{array}$ & No & & NA & $\checkmark$ & $\checkmark$ & NA \\
\hline \multirow[t]{3}{*}{$\begin{array}{l}\text { Local } \\
\text { community }\end{array}$} & $\begin{array}{l}\text { Health and } \\
\text { safety (living } \\
\text { environment) }\end{array}$ & $\begin{array}{l}\text { Extensive } \\
\text { negative } \\
\text { impacts }\end{array}$ & & $\checkmark$ & $\checkmark$ & $\checkmark$ & $\checkmark$ \\
\hline & $\begin{array}{l}\text { Community } \\
\text { engagement }\end{array}$ & No & & $\checkmark$ & $\checkmark$ & NA & $\checkmark$ \\
\hline & $\begin{array}{l}\text { Local } \\
\text { employment }\end{array}$ & Yes & & NA & NA & NA & $\checkmark$ \\
\hline \multirow[t]{2}{*}{ Society } & $\begin{array}{l}\text { Public } \\
\text { contribution } \\
\text { to sustainable } \\
\text { issues }\end{array}$ & No & & $\checkmark$ & $\checkmark$ & NA & $\checkmark$ \\
\hline & $\begin{array}{l}\text { Contrib. to } \\
\text { eco. } \\
\text { development }\end{array}$ & Yes & & NA & NA & NA & $\checkmark$ \\
\hline \multirow[t]{2}{*}{$\begin{array}{l}\text { Value chain } \\
\text { actors }\end{array}$} & $\begin{array}{l}\text { Promotes } \\
\text { social } \\
\text { responsibility }\end{array}$ & No & & $\checkmark$ & $\checkmark$ & NA & $\checkmark$ \\
\hline & $\begin{array}{l}\text { Fair } \\
\text { Competition }\end{array}$ & No & & NA & $\checkmark$ & NA & $\checkmark$ \\
\hline \multicolumn{8}{|c|}{$\begin{array}{l}\text { Colours are used to indicate the overall impact or performance assessment of a subcategory: red } \\
\text { (negative), green (positive) and white (indifferent). To show relationship of a subcategory to the impact } \\
\text { category, " } \checkmark \text { " is used. If there is no relationship between the subcategory and impact category, it is } \\
\text { marked as not applicable (NA). }\end{array}$} \\
\hline
\end{tabular}

There are no causal relationship models available for impact assessment when inventory data have been collected in SLCA. Hence, there is always subjectivity involved in this assessment and therefore transparency is crucial. The rules for assessment applied in this case study are explained in detail in Paper II.

The inventory analysis showed that there are various pieces of legislation and standards in Pakistan related to the subcategories under 
consideration in this SLCA, but they are not implemented. This was assessed as leading to negative social impacts for most, but not all, subcategories (Table 6).

The workers in the informal e-waste business in Pakistan work for more than $72 \mathrm{hrs} /$ week, which is more than the accepted ILO standard of 48 $\mathrm{hr} /$ week. Child labour is a common sight in this business. This is again in violation of human rights and ILO legislation. The working conditions are toxic due to the informal recycling processes and cause negative health and safety conditions. E-waste recycling is an informal business and no contracts exist between employers and workers, and therefore there is no social security that covers workers' benefits. These four subcategories were assessed as having negative social impacts (Table 6). On the other hand, forced labour was not seen in the business and it was seen that workers were willing to participate in the activities, as they are well paid compared with other jobs and require less expertise. The wages exceeded USD 2.7 per day, which is just enough to keep these workers above the poverty line. There was no discrimination seen or reported in this business. Women and children are given equal wages and opportunities to work in the business. Given that these three categories were in line with norms and standards, they were assessed as indifferent (Table 6). There are no unions, no freedom of association and workers have no right to put forward their demands. Therefore this led to negative social impacts.

In the case of the local community, the toxic processes involved in informal recycling cause extensive negative impacts on their living environment. As there is no-one to ensure community engagement, no efforts are made to improve the living conditions or public awareness, which was also assessed as causing negative social impacts (Table 6). As 
the e-waste recycling business is profitable and easy to enter, it has provided the local community with a livelihood and promotes local employment, which is one of the major positive impacts of this business.

In the case of the general population of Pakistan, it was seen that important stakeholders such as the government, NGOs, producers etc. were missing. Therefore there was no-one to ensure commitment to sustainability issues. At the same time, these e-waste/second-hand imports are necessary to provide the population of Pakistan with access to cheap ICT products. They are also a source of raw material for industries in Pakistan and they provide income for many involved in this business. These aspects contribute positively to economic development.

In the case of value chain actors, it was seen that the value chain actors involved lacked the initiative to promote social responsibility. This was due to lack of interest and, in some cases, due to lack of awareness. This led to negative social impacts. The mafia plays a negative role in controlling unfair market prices, thus causing unfair competition which leads to negative social impacts.

Informal electronic waste recycling overall has negative social impacts except for the fact that it promotes local employment and its contribution to economic development of the country. It is a source of cheaper ICTs for the population of Pakistan. It also provides raw material for industries in Pakistan. Yet lack of awareness among the various stakeholders makes it difficult to control this dangerous business and lack of involvement by government as the main stakeholder furthers worsens the situation, whereas government involvement could play a vital role in improving the situation. The lack of social responsibility exhibited by the value chain actors adds to the negative impacts. 


\section{Discussion}

Papers I and II in this thesis revealed that the informal e-waste recycling business in Pakistan is both economically important and at the same time a toxic business. Paper I showed that the profitability of this business has attracted many to work in the business, especially those living below the poverty line in Pakistan. A huge number of stakeholders with specific roles are involved in the e-waste recycling business, from the recycler/ exporter in the developed country to the scrapper in Pakistan. Ewaste is the source livelihood for all these stakeholders, which makes it difficult to control the sector.

In Paper I, the literature review showed that there are several loopholes in the Basel Convention and weak enforcement of legislation possibly leads to the transboundary movement of e-waste. This is the case in Pakistan, as e-waste is shipped from various developed and developing countries to Pakistan despite all the legislation and EPR in developed countries. Mislabelling, a similar coding system as for new products and lack of awareness among customs officers makes it easier for the e-waste to enter Pakistan. There is a need to strengthen EPRs and awareness along the line of authorities in both developed and developing countries in order to control flows of e-waste. There is also the need for transparency in these transboundary flows. The legislation and EPR need to be strengthened/introduced in both developed and developing countries. Separate coding should be introduced for new and old electronic equipment, so these are identifiable by the customs authorities. In developing countries such as Sri Lanka and Iran, one of the best possible solutions to the e-waste problem has been found to be 
implementation of EPR (Mallawarachchi et al., 2012; Taghipour et al., 2012).

High e-waste flows are forced into Pakistan and other developing countries due to the high dependence of the population on this low-priced ICT equipment to mitigate the digital divide. This drives the need for imports of such equipment into Pakistan. As there is little guarantee and lack of transparency on the condition of the equipment, there is a risk that the majority of the equipment imported ends up in the informal chains. Lack of formal recycling facilities is also a reason why e-waste ends up in the informal sector. The lack of producer responsibility and the absence of producers as stakeholders also direct e-waste towards the informal recycling sector. There have been several projects by producers of ICT in developing countries (e.g. HP, 2012) in attempts to formalise or improve this business, but this kind of initiative has been lacking in Pakistan. Such programmes ensure workers' safety and seek to minimise the environmental damage. There is a need to formalise this business or to introduce formal e-waste recycling and integrate the informal recycling business into the formal sector. Such initiatives have been discussed in several studies (Chi et al., 2011; Masood et al., 2013) and could result in a possible solution where e-waste imports into Pakistan continue, but end up in formal e-waste recycling systems.

The process of informal e-waste recycling in Pakistan is done through crude processes and basic tools. The people involved use little or no protective gear while processing this e-waste. These processes are equally damaging to the health of the workers and to the surrounding environment. There is no monitoring of these activities by environmental agencies, NGOs or government, and consequently tackling this issue is difficult. The government, environmental agencies, NGOs etc. are some of 
the stakeholders that can play a vital role in improving the situation in Pakistan. They currently lack information regarding the impacts and consequences of the business and this impairs their ability to contribute. Informal e-waste recycling in Pakistan is a market-driven business with a lack of transparency and accountability at all levels. The role of the media and NGOs in India and China has been positive in bringing the voice of the community to decision makers (Harashima, 2000) and has been supporting the bottom-up approach in these developing countries. This has improved the situation as regards various environmental issues.

Overall, in accordance with the Lemos and Agrawal (2006) hybrid governance concept, informal e-waste recycling in Pakistan shows a lack of government initiative and a lack of community involvement in seeking to improve the system. Despite existing legislation, the business operates against the rule of law and lacks accountability and transparency. There are huge numbers of stakeholders involved, but they lack the initiative to improve the system. There are also missing stakeholders, such as government and NGOs. The whole system lacks a decentralised governance structure and top-down and bottom-up approaches where all stakeholders are equally involved in improving the business and its governance weaknesses.

Informal e-waste recycling and imports of ICT e-waste have become an important economic activity in Pakistan, where various stakeholders are dependent on these as their source of livelihood. It is important that the flow of these imports to Pakistan continues, but efforts need to be made to reduce the negative impacts of related activities.

In Paper II, it was shown that this business has positive impacts when considering societal and personal/family economics, but otherwise it has 
mainly negative impacts. It was seen in the worker categories that there are several pieces of ILO legislation in place, but they are not being observed, leading to negative social impacts. It was also seen that as informal e-waste recycling is a source of livelihood for many, it has positive impacts in improving the living standard of the stakeholders involved.

It was seen in some cases, for example wages, that the subcategory met the norms; the wages were comparatively better than those in other similar occupations. However, this was not assessed as positive, but indifferent (see Table 6). This was because we chose to assess a subcategory as positive only if there was a net positive impact of an activity on the stakeholder. At the same time, it should be considered that in the case of developing countries such as Pakistan, meeting the norm itself may be a significant improvement compared with general practice.

During the work performed in this thesis, it was seen that there was lack of government as a stakeholder and this worsened the situation for the local community. The social impacts could have been improved with initiatives by government. Lack of awareness among workers and the local community also contributes to negative social impacts. Most of the value chain actors lack the responsibility to improve the social conditions of the business, and thus the negative impacts continue. There is a need to initiate government- or NGO-organised awareness raising programmes to mobilise the community to adopt safer working conditions and environmentally friendly processes.

It was also seen that SLCA had several weaknesses when used for assessing such an informal business. As SLCA is mostly designed for formal businesses or multinational companies with formal processes, this 
made it difficult to assess an informal process such as informal e-waste recycling. As this business lacks any formal contracts and documentation, most of the data used in the analysis were based on interviews and observations. There was also no specific way to conduct the impact assessment, the impact assessment process lacks impacts pathways, and the subjective nature of the assessment makes it a difficult task to assess the impacts. Many efforts were made to make the assessment process as objective and transparent as possible.

There have been very few previous studies regarding the impacts of informal recycling in Pakistan. The work presented in this thesis can provide a baseline for future studies. It can also help fill data gaps on the impacts of ICT when considered in a life cycle perspective. 


\section{Conclusions}

The amounts of e-waste being produced are increasing dramatically all around the world. Tackling these amounts of e-waste has become a challenge for both developing and developed countries. E-waste is toxic but is also a very valuable waste stream. It is important to recycle this waste stream in order to reduce the overall impact caused by the production of these products, by recovering the component materials and rare precious metals.

This thesis provides a clearer picture of the informal e-waste recycling business in Pakistan; the e-waste flows, existing business structure, the stakeholders involved and their roles and the possible economic, social and environmental impacts of the business. These results provide a baseline for future studies on e-waste in Pakistan. As the processes of informal e-waste recycling are similar in other developing countries, the results can also help provide baseline data on the social impacts of informal recycling in these other countries. The thesis also provides data for analysis of impacts of ICTs when considered in a life cycle perspective, highlights governance issues of the informal e-waste recycling business and identifies the social impact hotspots of the business. This can assist in decision making at different levels to improve the situation. The results also highlight the role that the governments of both developed and developing countries, NGOs and the producers of ICT can play in improving the informal e-waste recycling business around the world. 
Overall, it was concluded that:

- There are existing loopholes in both local and international legislation that force the flow of e-waste towards developing countries.

- There are a number of governance issues which allow this business to continue to grow in Pakistan.

- There are important stakeholders missing from the informal ewaste recycling sector that could contribute positively to improving the situation if they played an active role in the business.

- There is a need for e-waste flows to continue to Pakistan in order to sustain the livelihood of many people in Pakistan.

- Awareness raising is required at all levels throughout the system to improve this business.

- The informal e-waste recycling business has potential social impacts on the various stakeholders involved in this business. 


\section{How to improve e-waste recycling in Pakistan}

One of the possibilities to improve the e-waste problem in Pakistan is to partly or fully formalise the system. In partial formalisation, which is an existing process in Pakistan, e-waste is manually dismantled and the toxic part of this e-waste is sent back to the developed countries for formal recycling. As manual dismantling is a laborious process, outsourcing this task to Pakistan cuts the cost of recycling in the developed country. The part which is shipped to developed countries for recycling is the most toxic and profitable part and thus the stakeholders get to keep their profits and the impacts are reduced significantly. In this case, the dealers in Pakistan need awareness regarding this business and how it can benefit them and potential recyclers need to be contacted in developed countries. A few of these located in Belgium and Korea are already in business with recyclers in Pakistan.

Formal recycling can also be introduced in Pakistan, as has been seen in China and India. Although it has not been very successful in competing with the old and efficient informal sector (Chi et al., 2011), it can be one solution. This would require investment in infrastructure and some recycling companies from developed countries, which could benefit from lower-waged labour in Pakistan.

Companies such as Hewlett Packard have become in involved in projects in Africa, where they are managing e-waste recycling businesses (HP 2012). This has created about 2000 jobs and has had positive environmental, social and economic impacts. HP is working in collaboration with the Kenyan authorities to help develop national legislation, registration and infrastructure for responsible recycling. Such initiatives by producer companies such as HP, DELL etc. could play a 
similar role in improving the e-waste recycling business in Pakistan with the help of local government and NGOs.

Most producers consider waste management of their products to be their responsibility, which comes under the Corporate Social Responsibility (CSR) obligation. E-waste recyclers in Pakistan are workers contributing to managing the waste of these multinational companies. Therefore efforts to include benefits for these workers, such as providing basic protective gear, within CSR would also help improve the business. 


\section{Future research}

This field of informal e-waste recycling is more of a spatial problem, with its impacts spread across international boundaries. The environmental impacts of this informal e-waste recycling have to be studied in a life cycle perspective in order to obtain a better picture of the true impacts of ICT equipment. The economic aspects of this business need to be studied in detail. Material Flow Analysis (MFA) could help determine how much the informal e-waste recycling process helps in recovering materials, as it has diverse dynamics and sets criteria for various aspects that need to be explored. 


\section{References}

Arushanyan Y. (2013).LCA of ICT solutions: environmental impacts and challenges of assessment . Licentiate Thesis. TRITA-INFRA-FMS-LIC 2013:02, 2013

Awan AB and Khan ZA. (2014). Recent progress in renewable energy. Remedy of energy crisis in Pakistan. Renewable and Sustainable Energy Reviews. Vol.33, pp.236-253 [Peer Reviewed J ournal].

Babu RB., Parande AK. and Ahmed BC. (2007). Electrical and electronic waste: a global environmental problem. Waste management \& research. The J ournal of the International Solid Wastes and Public Cleansing Association, ISWA. Vol.25 (4), pp.307-18 [Peer Reviewed J ournal]

Bandyopadhyay A. (2010). Electronics Waste management: Indian Practices and guidelines. International J ournal of Energy and Environment. Vol.1 (5), pp.793-804.

Bartle I., Bache I. and Flinders M. (2012). Rethinking governance: towards a convergence of regulatory governance and multi-level governance? Paper for the ECPR Standing Group on Regulation and Governance 4th Biennial Conference, University of Exeter, 27-29June 2012.

Basel Action Network (BAN). (2002). Exporting Harm the high tech trashing of Asia. http:// www.ban.org/ E-waste/ technotrashfinalcomp.pdf. Retrieved on 30 April 2011.

Basel Action Network (BAN). (2005). The digital dump exporting reuse and abuse to Africa. http:// www.ban.org/ Ewaste/ technotrashfinalcomp.pdf. Retrieved on 30 April 2011. 
Bauer A., Hasan R., Magsombol R. and Wan G. (2008). The WorldBank's New Poverty Data: Implications for the Asian Development Bank. http:// www.adb.org/ Documents/ Presentations/ New-PovertyEstimates/Poverty-Data- Implications.pdf. Retrieved on 30 April 2011.

Benoît C., Mazijn B., et al. (2009). Guidelines for Social Life Cycle Assessment of Products, UNEP/ SETAC Life Cycle Initiative. Available at http:// www.unep.fr/ shared/ publications/pdf/ DTIx1164xPAguidelines_sLCA.pdf. Retrieved on $30 \mathrm{~J}$ une, 2012.

Blood P. (1994). Pakistan: A Country Study. Washington: GPO for the Library of Congress, http:// countrystudies.us/ pakistan/ . Retreived on 18 April, 2015.

Blue R., Hoffman R. and Berg LA. (2008). Pakistan Rule of Law Assessment the Final report. http:// pdf.usaid.gov/pdf_docs/PNADO130.pdf. Retrieved on April 18, 2015.

Brett HR. (2009). E-waste: An assessment of global production and environmental impacts. Science of the Total Environment. Vol.408 (2), pp.183-191[Peer Reviewed J ournal]

Chi X, Streicher-Porte M, Wang YLM. and Reuter M. (2011). Informal electronic waste recycling: A sector review with special focus on China. Waste Management. Vol. 31. pp. 731- 742.

European Commission (EC). (2003). Directive 2002/ 96/ EC of the European Parliament and of the Council of the 27J anuary 2003 on waste of electrical and electronic equipment J ournal of the EU L3. pp. 24- 38. 
Franze J . and Ciroth A. (2011). A comparison of cut roses from Ecuador and the Netherlands. The International J ournal of Life Cycle Assessment. Vol. 16, Issue 4, pp. 366-379.

Davis G and Herat S. (2008). Electronic waste: The local government perspective in Queensland, Australia. Resources, Conservation and Recycling. Volume 52, Issues 8- 9, pp. 1031- 1039.

Ewaste. (2011). Electronic Waste by Numbers: Recycling \& the World.http:// www.ewaste.com.au/ ewaste-articles/ electronic-waste-bynumbers-recycling-the-world/ Retrieved on 26 April, 2011.

Gabol AW and Ahmed A. (2011). Academic J ournals Full Length Research Paper Identification of future environmental challenges in Pakistan by 2025 through environment foresight Pakistan Technology Board, Ministry of Science and Technology, Islamabad, Pakistan. African J ournal of Environmental Science and Technology. Vol. 5(10), pp. 807814.

Greenpeace. (2009). Where does e-waste end up?http:// www.greenpeace.org/ international/ en/ campaigns/ toxics/ elect ronics/the-e-waste-problem/ where-does-e-waste-end-up/ . Retrieved on 26 April 2011.

GSMA. (2011). African Mobile Observatory 2011 Driving Economic and Social Development through Mobile Services http:// www.gsma.com/ spectrum/wp-content/ uploads/2011/ 12/ AfricaMobile-Observatory-2011.pdf. Retreived on May 15, 2013. 
Harashima Y. (2000). Environmental Governance in Selected Asian Countries. International Review for Environmental Strategies. Vol. 1, no 1, pp. 193-207.

Hester ER. and Harrison MR. (2009). Electronic Waste Management. pg. 213. RSC publishing.

Hewlett Packard HP. (2012). Resolving electronic recycling challenges in Africa. http:// www8.hp.com/uk/ en/hp-information/ environment/ ewaste-africa.html. Retrieved on 26 April 2013.

Hussain F. (2011). The J udicial System of Pakistan.

http:/ / www.supremecourt.gov.pk/ web/ user_files/ File/ thejudicialsystem ofPakistan.pdf. Retrieved on April 18, 2015.

ISO 14044. (2006). Environmental management-Life cycle assessmentRequirements and guidelines International Standards Organization Geneva, Switzerland

J orgensen A., Bocq LA., Nazarkina L. and Hauschild M. (2008).

Methodologies for Social Life Cycle Assessment. International J ournal of Life Cycle Assessment. Vol. 13 (2), pp.96-103.

Khurrum M., Bhutta S., Omar A. and Yang X. (2011). Electronic Waste: A Growing Concern in Today's Environment. Economics Research International. Vol. 2011. Article ID 474230, 8 pages, 2011.

doi:10.1155/2011/474230.

Knoth R. (2009). Scraplife-Ewaste in Pakistan.

http:/ / www.greenpeace.org/ international/ en/multimedia/multimediaarchive/ Photo-Essays1/ scrap-life-pakistan-with-rob/ . Retrieved on 03 April 2015. 
Ladou J and Lovegrove, S. (2008). Export of Electronics Equipment Waste. International J ournal of Occupational and Environmental Health. Vol. 14(1), pp.1-10.

Lemos CM. and Agrawal A. (2006). Environmental Governance. Annu. Rev. Environ. Resour. 31:297- 325

Lepawsky J . and Mcnabb C. (2010). Mapping international flows of electronic waste. Canadian Geographer-geographe Canadien. Vol. 54(2), pp.177-195.

Li YXJ ., Xu KS., Wu GJ ., Chen JX., Liu SJ ., Chen et al. (2008).

Monitoring of lead load and its effect on neonatal behavioral neurological assessment scores in Guiyu, an electronic waste recycling town in China. J Environ Monit. Vol. 10, pp. 1233- 1238.

Mallawarachchi H. and Karunasena G. (2012). Electronic and electrical waste management in Sri Lanka: Suggestions for national policy enhancements. Resources Conservation and Recycling. Vol. 68, pp.44-53 [Peer Reviewed J ournal]

Manhart A., Osibanjo O., Aderinto A. \& Prakash S. (2011). Informal ewaste management in Lagos, Nigeria - socio-economic impacts and feasibility of inter-national recycling co- operations. Institute for Applied Ecology, Final report of component 3 of the UNEP SBCE-waste Africa Project, Lagos and Freiburg.

Masood M and Barlow CY. (2013). Framework for integration of informal waste management sector with the formal sector in Pakistan. Waste Management \& Research. Vol. 31 (10_suppl), pp.93-105. 
Needhidasan S., Samuel M. and Chidambaram R. (2014). Electronic waste - an emerging threat to the environment of urban India. J ournal of Environmental Health Science and Engineering. Vol. 12, pp.36.

Nizami AT., Rana MH., Hassan TM. And Minhas FA. (2014). Terrorism in Pakistan: A Behavioral Sciences Perspective. Behavioral Sciences \& the Law. Vol. 32(3), pp. 335-346 [Peer Reviewed J ournal].

Ongondo FO., Williams ID. and Cherrett TJ . (2011). How are WEEE doing? A global review of the management of electrical and electronic wastes. Waste Management. Volume 31, Issue 4, pp. 714-730, ISSN0956053X,10.1016/j.wasman.2010.10.023.

Osibanjo O. and Nnorom I. (2007). The Challenges of electronic waste (ewaste) management in developing countries. Waste Management and Research. Vol. 25 (6), pp. 489-501.

Oteng - Ababio M. (2010). E-waste: an emerging challenge to solid waste management in Ghana. (Report) International Development Planning Review. Vol. 32 (2), pp.191(16).

Premalatha M., Abbasi T., Abbasi T. and Abbasi AS. (2013). The generation, impact, and management of E-waste: State-of-the-art. Critical Reviews in Environmental Science and Technology.

Rehman S. (2014). Geostrategic importance of Pakistan. http:// www.slideshare.net/ sohailahmedsolangi/ geo-strategicimportance-of-pakistan-by-shafiq-urrehman. Retreived on March 28, 2015. 
Sinha-Khetriwal D., Kraeuchi P. \& Schwaninger M. (2005). A comparison of electronic waste recycling in Switzerland and in India. Environmental Impact Assessment Review. Vol. 25(5), pp. 492-504.

Sthiannopkao S, Wong MH. (2013). Handling e-waste in developed and developing countries Initiatives, practices, and consequences. Science of the Total Environment. Volumes 463-464, Pages 1147- 1153.

Streicher-Porte M, Widmer R., J ain A., Bader H., Scheidegger R. and Kytzia S. (2005). Key drivers of the e-waste recycling system: Assessing and modelling e-waste processing in the informal sector in Delhi. Environmental Impact Assessment Review. Vol. 25(5), pp.472-491.

Sutinen GJ . (2000). A Framework for Monitoring and Assessing Socioeconomics and Governance of Large Marine Ecosystems. NOAA Technical Memorandum NMFS-NE-158.

Swedish Environmental Protection Agency (SEPA). (2011). Recycling and disposal of electronic waste Health hazards and environmental impacts. Swedish Environmental Protection Agency, Report 6417.http:/ / www.naturvardsverket.se/ Documents/ publikationer6400/97 8-91-620-6417-4.pdf. Retrieved on 21 November 2013.

Taghipour H., Nowrouz P., J afarabadi MA., Nazari J ., Hashemi AA., Mosaferi M. and Dehghanzadeh R. (2012). E-waste management challenges in Iran: presenting some strategies for improvement of current conditions. Waste Management and Research. Vol. 30(11), pp.1138-1144.

Takeback Coalition. (2009). What Happens To Our E-Waste? http:// www.electronicstakeback.com/ wpcontent/ uploads/E_Waste_tras hed_v_recycled. Retrieved March 23, 2013. 
Tanskanen P. (2013). Management and recycling of electronic waste. Acta Materialia. Vol. 61(3), pp.1001-1011.

The Economist. (2011). Economic problems of Pakistan.

http:// www.economistpakistan.com/Link-Detail.php?id=47. Retreived on March 28, 2015.

The Heritage Foundation. (2015). Pakistan.

http:// www.heritage.org/index/ country/ pakistan. Retreived on March 28, 2015.

United Nations Environmental Programme (UNEP) (2011) Recycling Ewaste to resources. http:// www.unep.org/pdf/Recycling_From_ewaste_to_resources.pdf.

United Nations University (UNU). (2007). Review of Directive 2002/ 96 on Waste Electrical and Electronic Equipment. Final Report.

http:/ / ec.europa.eu/ environment/ waste/ weee/pdf/final_rep_unu.pdf.

Wagner TP. (2009). Shared responsibility for managing electronic waste: A case study of Maine, USA Waste Management. Vol. 29(12), pp.30143021.

Wang FJ ., Huisman A., Stevels C. and Baldé P. (2013). Enhancing e-waste estimates: Improving data quality by multivariate Input- Output Analysis. Waste Management. Vol. 33, pp.2397- 2407.

Wei, L. and Liu, Y. (2012). Present Status of ewaste Disposal and Recycling in China. Procedia Environmental Sciences. Vol. 16, pp.506514. 
Williams E., Ramzy K., Braden A., Edward K., J unbeum K. and Ming X. (2008). Environmental, Social, and Economic Implications of Global Reuse and Recycling of Personal Computers. Environmental Science \& Technology. Vol. 42(17), pp.6446-6454.

WorldBank. (1999). Good Governance: An overview. IFAD INTERNATIONAL FUND FOR AGRICULTURAL DEVELOPMENT Executive Board Sixty-Seventh Session Rome, 8-9 September 1999.

WorldBank. (2015a). Data by country. http:/ / data.worldbank.org/indicator/ AG.SRF.TOTL.K2 Retreived on March 28, 2015.

WorldBank. (2015b). Data by country. http:// data.worldbank.org/indicator/ NY.GDP.PCAP.CD. Retrieved April 18, 2015.

WorldBank. (2015c). Data by country. http:/ / data.worldbank.org/ country/ pakistan. Retreived on March 28, 2015

Worldmeter. (2015) http:/ / www.worldometers.info/ worldpopulation/pakistan-population/ . Retreived on March 28, 2015.

Yu J., Williams E. and Ju M. (2010) Analysis of material and energy consumption of mobile phones in China. Energy Policy. Vol. 38(8), pp.4135-4141. 